\title{
See, Now They Vanish: Third-Person Perfect Auxiliaries in Old and Middle Czech*
}

\author{
Stephen M. Dickey
}

Abstract. This article argues that Czech retained a semantic distinction between the expression of current relevance/emphasis and a neutral preterit in third-person compound preterit forms until the late sixteenth century. The distinction was expressed by the presence (expressing current relevance/emphasis) vs. absence (neutral preterit) of third-person auxiliaries. The hypothesis is based on data from two late fourteenth-century narratives (Asenath and The Life of Adam and Eve) and from letters written by or to Czech women from 1365 to 1615 . The results of statistical analyses are presented as support for the hypothesis, and it is suggested that the continued distinction between current relevance/emphasis and a neutral preterit in the third person is in part responsible for the fact that the two-way use of imperfective verbs never became a major usage pattern in Czech, in contrast with Russian, where the tense system was reduced relatively early.

\section{Background: The Loss of the Compound Perfect in North Slavic}

It is well known that the compound perfect of Late Common Slavic, which consisted of a present-tense form of byti 'be' and the stative $l$ participle of the main verb, e.g., Old Church Slavic (OCS) esmb obidélt 'I have offended', has become a general preterit in all the North Slavic languages (for a recent discussion, see Tommola 2000). This development was set into motion as the simple past tenses (imperfect and especially aorist) began to disappear. Though the initial situation (the existence of all three past tenses in the tenth century) and final out-

\footnotetext{
* This article was written while I was at the Centre for Advanced Study in Oslo, Norway. I would like to extend my heartfelt thanks to the center's staff for their support and gracious assistance, and also to Laura Janda and Tore Nesset, the leaders of the Time is Space group, and its other members for their support as well as much feedback and advice on this paper. I would also like to thank Ronald Langacker for providing feedback on the subjectification analysis in section 2, and to Frank Gladney for some minor corrections. Naturally, I alone am responsible for any errors contained herein.
}

Journal of Slavic Linguistics 21(1): 77-121, 2013. 
come (the existence of reflexes of the erstwhile compound perfect as a general preterit in the modern languages) are known, the details of the process are less clear. It seems evident that the loss of the imperfect and aorist was the catalyst for the expansion of the compound perfect into a general preterit. Note that in East Slavic and Polish the compound perfect became a simple preterit (though Polish retained remnants of the auxiliaries as inflectional endings), as all auxiliary forms were lost, whereas the non-Lekhitic West Slavic languages kept the auxiliaries except for the third-person forms as clitics.

Xaburgaev (1978) has argued that the loss of the aorist and the accompanying expansion of the perfect, including the loss of its auxiliaries, was completed very early in Russian. The aorist was apparently lost by the eleventh century. Table 1 reproduces Xaburgaev's (1978: 46) table of the chronology of the loss of the auxiliaries.

Table 1. The Stages of the Loss of the Perfect Auxiliaries in East Slavic according to Xaburgaev (1978: 46)

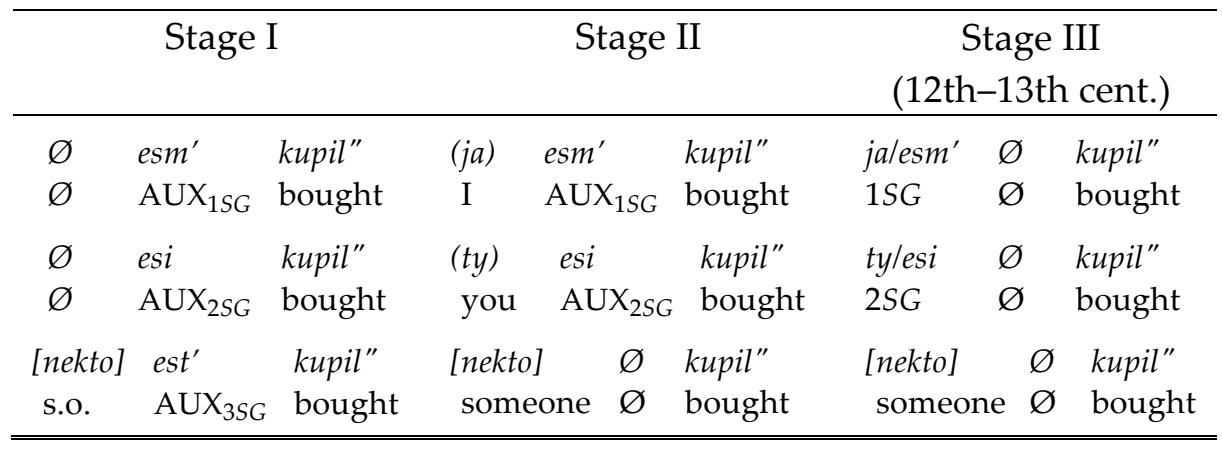

The third-person auxiliaries were lost first; then the auxiliaries of the first and second person became person markers and were later phased out of that function, being replaced by pronouns.

Even if the process was not completed everywhere as early as Xaburgaev claims, ${ }^{1}$ the process must have occurred relatively early in East Slavic in comparison with West Slavic, especially Czech. Note that the Novgorod birchbark documents show a situation in the eleventh century in which the aorist was already lost, third-person auxilia-

\footnotetext{
${ }^{1}$ Cf. Darden 2004, who argues that the collapse of the old tense system occurred in northern Russian dialects before it did in southern dialects.
} 
ries were lost, and first- and second-person auxiliaries alternated with personal pronouns as markers of person (cf. Zaliznjak 2004: 142-43, 178-81). Zaliznjak (2008: 262) observes that in contrast to the early loss of the third-person auxiliaries, it took until the seventeenth century for first- and second-person auxiliaries to disappear completely from the spoken language as person markers.

Polish lost its aorist by the fourteenth century. ${ }^{2}$ However, the subsequent evolution of the auxiliaries differed from the developments in East Slavic. The third-person auxiliaries were lost in the fourteenth century (cf. Decaux 1955: 116), and became emphasis markers, eventually for all persons (cf. Andersen 1987: 27-28), as exemplified in (1).

(1) To-m jest oglądała. (Old Polish; Andersen 1987: 28) that.1SG EMPH saw

'That I did see.'

Such usage disappeared in the sixteenth century, and reduced forms of the first- and second-person auxiliaries became inflectional endings added to the $l$-participle by the sixteenth century (e.g., zrobit-em 'I did', zrobit-eś 'you [sg] did' versus zrobit-ø 'he did'). Thus, Polish is characterized by a longer retention of third-person auxiliaries than East Slavic. Whereas much of East Slavic lost its third-person auxiliaries by the eleventh century, they appear to have been retained until the fourteenth century in Polish, whereupon the third-person forms were used for a time as person-neutral emphasis markers.

Czech has not been investigated in detail in this regard as far as I am aware. Unlike Russian and Polish, it has retained the auxiliaries of the old compound perfect as enclitics, except the third-person forms. According to Gebauer (1958: 65), the loss of the aorist in Old Czech got underway in the thirteenth and fourteenth centuries, and it disappeared completely by the end of the fifteenth century (the beginning of the Middle Czech period, which lasts until the sixteenth century). Lamprecht, Šlosar, and Bauer (1986: 244) observe that third-person forms of the Czech compound perfect appear without the auxiliary in the oldest texts, and that third-person auxiliaries were "already very

\footnotetext{
${ }^{2}$ Only relics are present in texts from the mid-fourteenth century; cf. DługoszKurczabowa and Dubisz 2001: 304 and the literature cited there.
} 
rare" at the beginning of the sixteenth century, though they do not specify the texts that served as the source for their claim.

This paper argues on the basis of data from two late fourteenth century narratives as well as Czech letters dating from 1365 to 1615 that Czech third-person auxiliaries retained an aspectual meaning into the sixteenth century. More specifically, Czech had a distinction between auxiliated and unauxiliated $l$-participles at this time that reflected a distinction in current relevance and/or emphasis versus a neutral preterit. ${ }^{3}$ The situation evident in these texts is examined and the implications for a theory of the development of Slavic aspect are considered.

\section{Theoretical Background: Approaches to the Loss of Third-Person Auxiliaries in the Slavic Compound Perfect}

This paper is ultimately concerned with a semantic distinction expressed by auxiliary variation in third-person forms of the compound perfect in Old and Middle Czech. However, as such auxiliary variation represents an intermediate stage of development from the original tense system of Late Common Slavic to the modern Czech system in which the general preterit has dropped the auxiliaries only in the third person and auxiliary marking serves to indicate person, I consider it not too far afield to propose a theory of why the third-person perfect auxiliaries would ultimately be dropped. To this effect, this section outlines a cognitive-grammar (CG) explanation of the loss of thirdperson auxiliaries in Czech, which may be valid for Polish and East Slavic as well. ${ }^{4}$ The CG explanation of the loss of the third-person perfect auxiliaries is given in section 2.2. Before this hypothesis is offered, however, two notions that might be taken as explaining this loss should be discussed briefly-markedness and redundancy. They are the topic of the next section.

\footnotetext{
${ }^{3}$ Unlike in Polish, however, in Czech the third-person auxiliaries did not become person-neutral emphasis markers.

${ }^{4} \mathrm{I}$ am unaware of any historical facts from these languages that would render it problematic. However, the histories of these languages cannot be discussed further here.
} 


\subsection{Markedness and Redundancy}

One sense of the term markedness refers to morphological marking: in a given language a given grammatical category may be morphologically marked, or it may be morphologically unmarked, i.e., zero-marked. The zero-marking of third-person verb forms is typologically common, as observed by Greenberg (1966: 44). It may therefore be tempting to attribute the loss of third-person perfect auxiliaries in Czech to a typologically common tendency to zero-mark third-person verb forms and leave it at that. However, such an approach is ill-suited for explaining the zero-marking of particular third-person verb forms in a particular language, for the simple reason that the general tendency noted by Greenberg is best viewed as the collective result of different (yet probably interrelated) factors affecting the coding of individual grammatical categories in different languages. That is to say, a typological generalization should not be casually invoked as an explanation of particular language data.

A further reason not to think of the loss of Czech third-person perfect auxiliaries in terms of a tendency to zero-mark third-person verb forms is that the third-person forms of byti 'be' were only lost as perfect auxiliaries, not in their function as copulas: Czech has retained je 'is' and jsou 'are' in this function. This suggests that there was something about the third-person auxiliaries of the compound perfect, as opposed to the third person in general, that was at work in this development. The CG approach offered in section 2.2 develops this idea and can account for the different fates of the third-person auxiliaries and copulas in Czech. ${ }^{5}$

Another possibility is that Czech third-person perfect auxiliaries were lost because of the redundancy of overtly marking the third per-

\footnotetext{
${ }^{5}$ These arguments also apply to the idea of the semantic unmarkedness of the third person formulated by Jakobson (1932/1971), who views the third person as "imperson$\mathrm{al}^{\prime \prime}$ in contrast to the first and second persons, which are "personal," and Lyons (1977: 638), who suggests that the third person is unmarked because it "is negatively defined with respect to 'first person' and 'second person': it does not correlate with any positive participant role." Though the unmarkedness of the third person for discourse participation cannot, in my view, directly explain the ultimate loss of third-person perfect auxiliaries in Czech, it could very well account for why auxiliary variation in Old and Middle Czech occurred only in the third person, which is not the same thing. See the comments at the end of section 2.2.
} 
son in verb forms. Andersen (2006: 243) has made this suggestion for Russian, noting that in Old Russian forms of the present tense of byti 'be' "were commonly omitted in contexts where they were redundant, first and foremost the third person forms, which typically agreed with a nominal subject" and subsequently referring to this redundancy as the "pragmatic motivation" for the loss of the auxiliaries (253). Along these same lines, Dahl (2000: 64-66) observes that reference to thirdperson entities recurs in discourse more than reference to first- or second-person entities, due to the topic status of the former, which "may help explain markedness patterns in verbal agreement systems."

Though Andersen's and Dahl's arguments make sense, I do not believe that they are directly relevant to the case of the Czech perfect. The non-Lekhitic West Slavic and South Slavic languages have existed for almost a millennium with the stable, overt coding of third person forms of 'be'. See, for example, the aforementioned Czech je 'is' and jsou 'are' as copulas as well as Bosnian/Croatian/Serbian (BCS) je 'is' and $s u$ 'are' as both copulas and auxiliaries. If redundancy is assumed to have been the motivation for the loss of Old Russian third-person forms of byti, the retention of third-person forms of the copula in Czech and the retention of third-person forms of the auxiliary in other Slavic languages require some explanation. Further, Zaliznjak (2008: 256-57) points out that in the birch bark documents third-person auxiliaries were commonly omitted even in the absence of an overt subject, as exemplified in (2).

(2) a mъně ne vъdastı ničsto že, izbivъ rouky poustilı že mę, a inouju poęlı (Zaliznjak 2008: 257) 'he doesn't give me anything, having beaten my arms he dropped me and took another [woman]'

Such data directly contradict the hypothesis that the auxiliary was omitted because it was redundant due to the presence of an overt subject. In this regard it should be pointed out that the overt coding of third-person subjects should be irrelevant for auxiliary variation in Czech, which is a pro-drop language (i.e., exhibits usage parallel to that in example (2)).

To recapitulate, it may be tempting to attribute the loss of thirdperson perfect auxiliaries in Czech to qualities of the third person itself, either in terms of the typological frequency of zero-marking of the 
third person or in terms of the redundancy of third-person agreement. However, I think that typological tendencies are insufficient for explaining data from particular languages. As regards the possibility of explaining this development as a consequence of the redundancy of third-person verb agreement, Old Russian data in fact shows the redundancy hypothesis to be problematic. It is also worth reiterating that the retention of third-person forms of byt $t$ 'be' as copulas in Czech suggests that a theory of the loss of its third-person perfect auxiliaries should take properties of past tenses into account. The next section offers such a theory in the framework of CG.

\subsection{A CG Account of the Loss of Third-Person Perfect Auxiliaries in Slavic}

The point of departure for the hypothesis presented here is that in the North Slavic languages there is a correlation between the loss of the simple preterits (the imperfect and perhaps more importantly the aorist) and the loss of the third-person perfect auxiliaries, as shown in Table 2:

Table 2. Retention of the Aorist and 3rd-Person Auxiliaries in North Slavic

\begin{tabular}{lcccc}
\hline Language & Sorb & $\mathrm{Cz}$, Slk & Pol & East Sl. \\
\hline Retention of aorist & Yes $^{6}$ & No & No & No \\
Retention of 3rd-pers. aux. & Yes & No & No & No \\
\hline \hline
\end{tabular}

Sorbian has retained an aspectually restricted simple preterit (i.e., aorist endings occur with perfective verbs, and imperfect endings occur with imperfective verbs). According to Tommola (2000: 454-56) the compound perfect can be employed in narration, and the simple preterit, while preferred in narration, is basically a stylistic variant. However, these facts do not negate the overall correlation, and I assume that if the compound perfect now competes with the simple preterit, the simple preterit was likely a neutral narrative mode in centuries

\footnotetext{
${ }^{6}$ As pointed out below, Sorbian has not retained an aorist, but has a synthetic preterit with aorist endings for pf verbs. The difference is irrelevant for the issue at hand.
} 
past. It is also possible that German language contact has played a role in the retention of the simple preterit and the retention of the thirdperson perfect auxiliaries, but this issue cannot be taken up here.

Inasmuch as the loss of third-person perfect auxiliaries is correlated with the loss of the aorist in North Slavic, we are justified in seeking a possible semantic connection between these two phenomena. ${ }^{7}$ The loss of the aorist cooccurs with the development of the compound perfect into a compound general preterit, i.e., the spread of the functional scope of the compound perfect beyond the expression of the current discourse relevance of an event to other functions, chiefly the narrative mode-telling what happened with a focus on past events themselves and not on their current relevance to the discourse/speech situation. And if the loss of the third-person aorist can be connected to

${ }^{7}$ In South Slavic one can detect the same correlation, in that the largest languages, BCS and Bulgarian, retain both the aorist and the third-person perfect auxiliaries, as shown in the following in Table I:

Table I. Retention of the Aorist and 3rd-Person Auxiliaries in South Slavic

\begin{tabular}{lllll}
\hline Language & Sln & BCS & Mac. & Bulg. \\
\hline Retention of aorist & No & Yes & Yes & Yes \\
Retention of 3rd-pers. aux. & Yes & Yes & No & Yes \\
\hline \hline
\end{tabular}

However, the South Slavic situation is messier, as Slovene has lost the aorist and kept third-person auxiliaries, and Macedonian has kept the aorist but lost third-person perfect auxiliaries.

As for Slovene, it is possible that German and/or Romance language interference has played a role. Reindl (2005: 164-65) is skeptical regarding the possibility of German language interference and suggests that the East Slavic languages are "anomalous" in their lack of auxiliaries. However, Reindl's observation is only relevant if one considers the overall lack of auxiliaries in East Slavic versus the general presence of auxiliaries in all of West and South Slavic apart from Polish. In contrast, if one correlates the retention of third-person auxiliaries to the recent existence of the aorist, then as pointed out it is Slovene that is anomalous.

The situation in Macedonian and Bulgarian is very complex and cannot be addressed in detail here. According to Friedman (1986), the presence versus absence of third-person auxiliaries varies according to dialect and idiolect, and the degree to which zero-marked l-participles express the renarrative mode is subject to debate. Fielder (2001) suggests that in Bulgarian the third-person auxiliary can only be dropped to express a distinction in evidentiality if a perfect interpretation is unavailable, i.e., the third-person auxiliary does in fact express current relevance. See below and the remarks in section 5 . 
the spread of the compound perfect to narrative contexts, then an explanation that naturally suggests itself is that the third-person perfect auxiliaries were dropped because their semantic contribution to the compound perfect construction was felt to be incompatible with the focus of narration on events themselves.

Though this hypothesis was developed independently, it is very much in the spirit of recent work by Fielder $(1998,2001)$. As mentioned in footnote 7, Fielder (2001) suggests that in Bulgarian the third-person auxiliaries still express current relevance (i.e., the perfect), and that "auxiliary variation cannot encode EVIDENTIAL if the l-participle occurs in a clearly perfect context because the perfect context requires the use of the auxiliary" (182). Similarly, Fielder (1998), in an examination of pre-nineteenth century Bulgarian texts, concludes that auxiliary variation with the $l$-participle initially expressed a distinction between the actional perfect (i.e., foregrounding; unauxiliated) and the statal perfect (backgrounding; auxiliated). Though there are certainly differences between the Bulgarian and Old and Middle Czech situations, if one factors out the salient evidential distinction in Bulgarian, the hypothesis advocated here is basically the same: the narrative mode makes the third-person auxiliary aspectually infelicitous, whereas the perfect requires it.

This hypothesis has the advantage of taking at face value the original function of the Slavic auxiliary byti 'be', i.e., the expression of current relevance through its profiling of a present-tense state. Moreover, it is not incompatible with the idea that the zero-marking of the third person correlates with high frequency (cf. Haspelmath 2006: 47), inasmuch as an important reason for the high frequency of third-person forms in the past tense is that we tend to narrate about third parties.

Let us now turn to a CG account of the loss of auxiliaries in the Czech compound preterit. This account relies in particular on Langacker's theory of subjectification as the attenuation of objective content. As just mentioned, this approach takes the function of the present-tense forms of byti 'be' as auxiliaries in early Slavic seriously: these present-tense forms asserted the current relevance of the postevent state profiled by an l-participle through their present-tense value. Thus, esmb obidělt 'be ${ }_{1 S G}$ offended' meant I am in a state of having offended. In other words, the present-tense state profiled by byti 'be' was essential for the construction, and the auxiliary was not simply a 
person marker. In terms of CG, the OCS perfect profiled a state at the time of utterance, as shown in Figure 1.

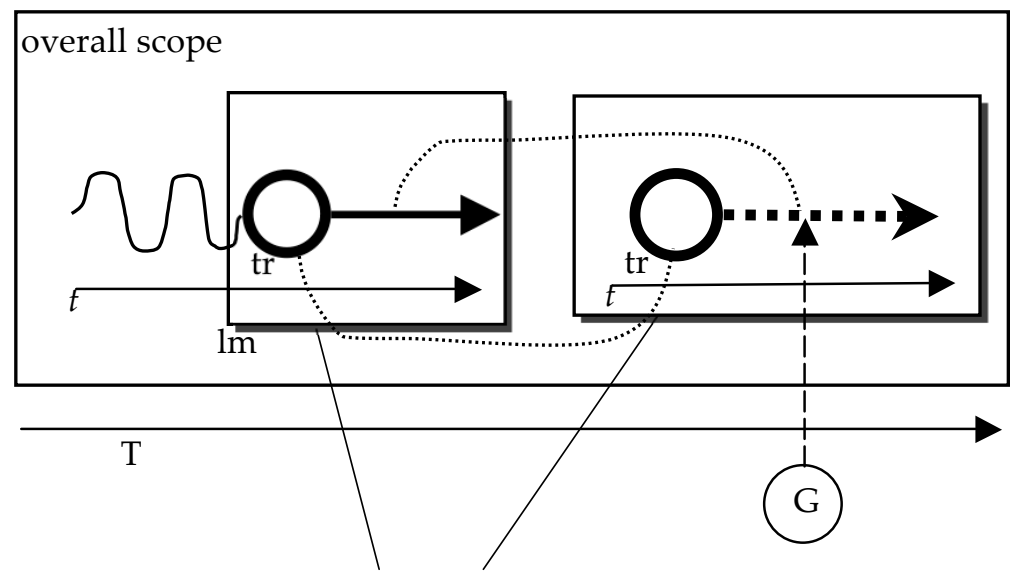

obidělı esmb 'I have offended'

Figure 1. The Stative Perfect in OCS

In Figure 1, esmb 'am' profiles a schematic (underspecified) state of the subject (trajector-tr) sequentially in time, which in this case is identical to the post-event state profiled by obidell 'having offended', as indicated by the thin dotted line connecting the arrows. Likewise the trajector of the participle is also identical to the trajector of the finite verb, as indicated by the thin dotted line connecting the trajectors. Note that the activity of the event itself (represented by the squiggly line) is not profiled in the immediate scope of the participle (being rather a part of its profile base). Thus, the auxiliary byti 'be' originally expressed the existence of the subsequent state expressed by an l-participle (e.g., obiderl 'having offended') simultaneous to the ground (G; the speech situation).

The next stage represents the subjectification of the schematic state profiled by the auxiliary: the profile of a state scanned sequentially in time is attenuated, and the auxiliary begins primarily to profile a reference point by which the event profiled by the participle is accessed, which in the default case is an element of the ground, in particular the speaker's domain of experience. ${ }^{8}$ However, it may be some other point

${ }^{8}$ I am grateful to Ronald Langacker for suggesting this idea. 
in time. ${ }^{9}$ This stage represents a system in which there are still thirdperson aorists and some first-person aorists, but no second person aorists, as in The Life of Adam and Eve. The default for the first and second persons is access through the reference point of the ground: this is why unauxiliated first- and second-person compound perfects do not occur. In other words, I assume that the motivation for the obligatory retention of the first- and second-person auxiliaries was that the firstand second-person past-tense predicates have a strong tendency not to be narration but statements of fact that relate to the current discourse exchange between speaker and hearer. The third-person perfect expresses this construal as well. This is diagrammed in Figure 2.

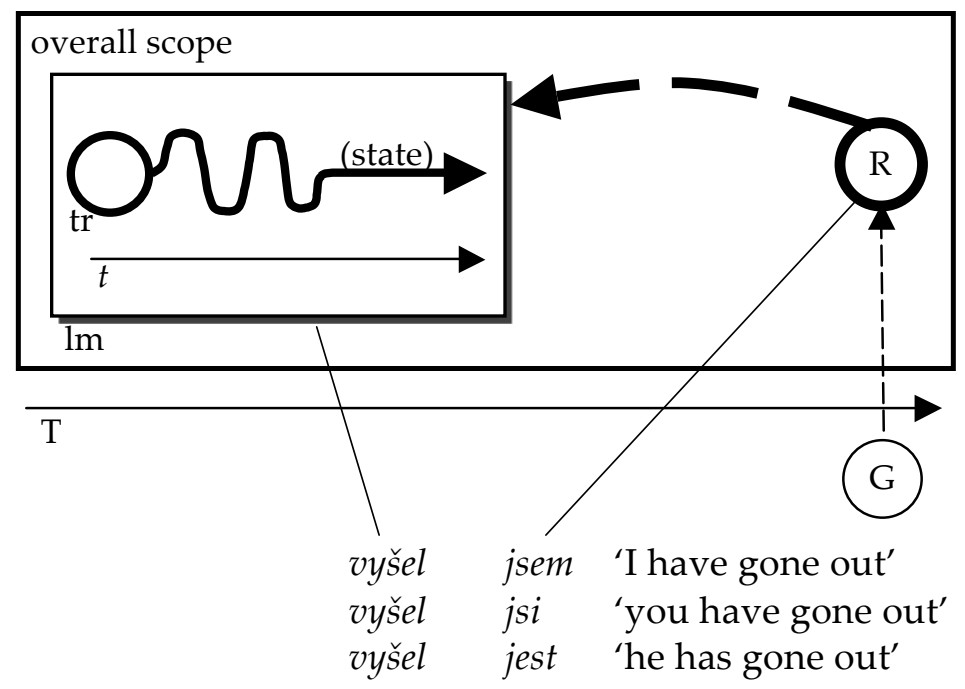

Figure 2. The Initial Stage of Subjectification of the Czech Compound Perfect

In Figure 2, the auxiliary refers primarily to a reference point by which the event and its subsequent state are accessed. At this stage the present-tense forms of býti 'be' still profiled a schematic state. However, I assume that this objective profile was attenuated, yielding merely a reference point that served as the point of access to the event. As men-

\footnotetext{
${ }^{9}$ Here with some alterations I am following Langacker's (1990: 340) account of the English have perfect as a reference-point construction resulting from the subjectification of the resultative have construction.
} 
tioned above, the reference point is the experiential domain of the speaker. In this way, the perfect construction underwent subjectification, passing from the originally objective construal of a stative perfect construction to the more subjective construal of an eventive perfect, which expressed a past event as having some present relevance (not necessarily limited to a state directly resulting from the event). ${ }^{10}$

At this stage, the unauxiliated third-person l-participle represented a simplified profile of a past event itself directly from the time of the ground, as shown in Figure 3.

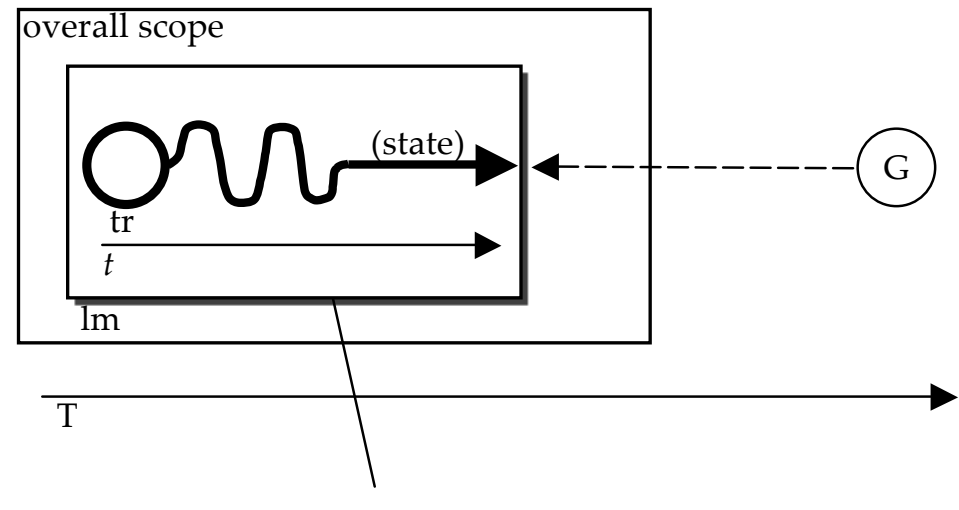

vyšel 'he went out'

Figure 3. The Unauxiliated Third-Person L-Participle of Old and Middle Czech

Figure 3 also represents the construal expressed by all persons of the compound preterit in modern Czech. The complete attenuation of the stative content contributed by the first- and second-person forms of by ti 'be' has resulted in the elimination of the reference point in the profile of the construction, leaving only the content of grammatical person as the information contributed by the auxiliary. In this view, I am basically following Langacker's (1999: 167-68) suggestion that the extreme subjectification of a be-auxiliary entails the complete attenuation of the schematic state that it profiles, because the participle pro-

\footnotetext{
${ }^{10}$ Note that in Old and Middle Czech the compound perfect occasionally functioned as a past perfect, which is why the profiled reference point is not necessarily an element of the ground itself.
} 
files the same state in more specific terms. This is the point where the auxiliaries become semantically empty inflectional markers of tense and person signaling that the event is accessed from the present. According to this hypothesis, the zero-marking of the third-person compound preterit became a zero-inflectional marker in contrast to the first- and second-person auxiliaries only after the PERFECT : NEUTRAL PRETERIT distinction was eliminated in the third person. Further, the definitive loss of the auxiliary in the third-person compound preterit was presumably due to the fact that third-person forms are employed very frequently in narration, so that the narrative use would gain status as the conceptual default of a third-person preterit form.

Here I would point out that the hypothesis outlined above can account for the disappearance of third-person perfect auxiliaries in contrast to the retention of third-person copulas in Czech. The complete attenuation of the schematic state profiled by by $t i$ 'be' and the resulting reduction of the profile of the construction to that of the process profiled by the participle can only occur in a verbal construction. In clauses with copulas, the atemporal relation profiled by an adjective and the (spatial) region profiled by a noun are not processes and do not profile the verbal state profiled by býti 'be' more specifically, and thus the complete attenuation of the schematic state profiled by být $i$ 'be' is not motivated.

Returning to the issue of the semantic unmarkedness of the third person mentioned in footnote 5, while such semantic unmarkedness cannot in my view directly motivate the complete loss of third-person perfect auxiliaries in Czech, it is easy to see how the unmarkedness of the third person in terms of participation in the discourse would result in auxiliary variation occurring only in the third person. Third-person entities might or might not be participating in a discourse: the actions of third-person entities who are discourse participants are accessed through the reference point of the ground by default, whereas the actions of those who are not are accessed directly, without asserting any current relevance.

To recapitulate briefly, according to the hypothesis presented here in Old and Middle Czech the l-participle with a third-person auxiliary (e.g., vyšel jest 'he AUX went out', vyšli jsú 'they AUX went out') signaled that the event was being accessed from a reference point, the speaker's experiential domain as an element of the ground by default, with the concomitant effect of a perfect construal or emphasis on the 
current relevance of an individual event. The unauxiliated third-person l-participle (e.g., vyšel 'he went out', vyšli 'they went out') was a neutral preterit. Section 3 examines two fourteenth-century narrative texts and letters from the fourteenth to the seventeenth century using the CG account outlined above as a point of departure.

\section{Data and Overall Analysis}

This section examines auxiliary variation for the Old and Middle Czech compound preterit in order to determine what factors triggered the presence versus absence of the auxiliary. The background for the analysis is the conservative system in the Alexandreis (from the latter fourteenth or early fifteenth century). Three data sets are examined. The first two are Asenath (Asenech) and The Life of Adam and Eve (Život Adama a Evy), two Old Czech narrative texts dating from the late fourteenth century which are translations from Latin. The third and largest consists of letters written by or to Czech women in the Old and Middle Czech periods, from 1365 to 1615, taken from Old Epistolary Texts of Czech Wives and Daughters (Staré písemné památky žen a dcer českých).

The letters complement the narrative texts in terms of text type. Though the letters contain much more direct discourse than the narratives, and though the bulk of the letters date from the fifteenth century and after, it is shown that all the three sources share more or less the same kind of auxiliary variation in the third person.

\subsection{Two Fourteenth-Century Narratives: Asenath and The Life of Adam and Eve}

In the fourteenth century the Czech verbal system was undergoing considerable changes. As mentioned in section 1, the loss of the aorist had already begun (Gebauer 1958: 65). And as Lamprecht, Šlosar, and Bauer (1986: 244) point out, unauxiliated $l$-participles of the compound perfect appear in the oldest texts. However, Dostál (1966: 81-82) argues that at this time the Czech simple preterits (aorist, imperfect) are sufficiently well represented in texts to support the conclusion that they were more than relic forms. Thus, though the compound perfect was showing signs of developing beyond the expression of resultant states, there were most probably still differences between the simple preterits and the spreading compound perfect. 
The result is variation from text to text in three respects: (i) the frequency of the aorist (and imperfect), (ii) the frequency of the compound perfect, and (iii) the frequency of unauxiliated forms of the third-person of the latter. The Alexandreis (Alex), conservative in style, contains high numbers of aorist and imperfect forms. Ordinary action verbs occur in the aorist, as shown in (3a), and it seems that the aorist is particularly common with verba dicendi $(3 a-b)$ and phase verbs (3c). An example of an imperfect is also given in (3b).

(3) a. A když se sjedechu $u_{A O R}$ ku přihlédaní množstvie lidu bez čísla, i věce ${ }_{A O R} \mathrm{k}$ svým Alexander: "Mužie stateční, kto z vás první počne hráti?"

(Alex: 53)

'And when great multitudes of men came together for the inspection, Alexander said to his men: "Brave men, who of you will begin to play first?"'

b. Tehdy odpověděchu $\mathbf{u}_{A O R}$ jemu od knieni panny, jížto bieše $\mathbf{I}_{I P F}$ jméno Kachora, že nebieše $\mathbf{I P F}_{I P} \mathrm{v}$ ta doby hodina dávati odpovědi bohové.

(Alex: 52)

'Then they answered to him from the princess, whose name was Kachora, that then it was not the appropriate time to give a divine answer.'

c. Uslyšev to Alexander, hned jest jel k němu a nalezl jest jej, an táhne k smrti, i poče ${ }_{A O R}$ nad ním hořce plakati. (Alex: 35)

'Alexander, having heard that, immediately rode to him and found him drawing close to death, and began to weep bitterly over him.'

Otherwise the Alexandreis employs third-person compound perfect forms, the great bulk of which contain auxiliaries; unauxiliated thirdperson $l$-participles are infrequent. Representative examples of auxiliated third-person $l$-participles are given in (4). 
(4) To učiniv Pausania, i zdvihl se jest $v$ zpupnost a všel jest směle na sien, aby odtad vyvedl Olympiadu královnu a aby ji sobě vzal za ženu.

(Alex: 34-35) 'Pausanias, having done that, "got AUX on his high horse" [rose up AUX into overbearingness] and boldly entered AUX into the palace, in order to remove princess Olympiades and make her his wife.'

Other texts show a newer system. Two of these are Asenath (Asenech, abbr. Asen) and The Life of Adam and Eve (Život Adama a Evy, abbr. $L A E)$, both date from the late fourteenth century. These two texts were chosen because of their age and their size (the former is approximately 3,500 words and the latter approximately 5,000 words), which allowed for all past-tense verb forms to be tagged and analyzed, yielding data sets from two different but more or less contemporaneous Old Czech texts. All the active past-tense verb forms from the two narratives were recorded, yielding a total of 747 tokens, which were described in terms of the following parameters: (i) auxiliation (auxiliated vs. unauxiliated vs. synthetic, i.e., aorist or imperfect), (ii) aspect (perfective vs. imperfective), (iii) subject (overt subject vs. no overt subject), (iv) grammatical person (first, second, and third; singular, dual, and plural), (v) discourse (main narrative vs. direct speech), (vi) sequencing (presence vs. absence of a context of narrative sequencing), (vii) reflexivity (reflexive vs. non-reflexive), and (viii) ATB, i.e., whether the predicate appears to be auxiliated by an across-the-board auxiliary (this was done based on clause structure with respect to the situation in contemporary Bosnian/ Croatian/Serbian). These parameters were chosen based on a hypothesis that auxiliation was conditioned by aspectual factors, agreement phenomena, or diathesis.

The fact that these two narrative texts are translations from Latin does have consequences for auxiliation, as it seems that the perfect forms of Latin deponent verbs (e.g., mortuus est 'he died') are fairly consistently translated with auxiliated verb forms, e.g., umřel jest 'he died'. However, if we attribute the auxiliation of translations of Latin deponent verbs to slavish imitations of the auxiliation of the originals, we must also wonder whether the unauxiliated Latin perfect (e.g., fecerunt 'they made') is also responsible for possibly unmotivated unauxiliated forms in the Czech translations. In any case, the tokens representing translations of Latin deponent verbs are a small minority 
and do not invalidate the overall statistical analysis presented here. Admittedly, the fact that it is the full form jest 'is' that is used in the third-person singular raises the issue of whether language contact was involved, either with Latin or German. Again, however, the statistical analysis presented below points to a real system. Note that there is no evidence that any of the letters analyzed in the third data set (see section 3.2) were translated, which indicates that the auxiliary variation was not merely a feature of translations from Latin.

Asenech and $L A E$ show a system in which aorists are few in number and unauxiliated l-participles are the most common mode of thirdperson narration. Representative examples of unauxiliated $l$-participles from each are given in (5):

(5) a. A posula popelem hlavu svú, položila se na paláci a plakala hořce sedm dní.

(Asen: 342)

'And she sprinkled her head with ashes, set herself upon the throne, and wept bitterly for seven days.'

b. A pro velikú mdlobu padla na zemi, i vzdvihl ji dábel vzhóru a dovedl ji k Adamovi.

'And she fell on the ground due to extreme fatigue, and the devil lifted her up and brought her to Adam.'

The numbers for the third-person forms of the compound perfect in Asen and $L A E$ are given in Tables 5 and 6, according to aspect and auxiliary variation. The numbers of aorists and imperfects in each are given under each table.

Table 5. Auxiliation of 3rd-person L-Participles in Asenech, by Aspect

\begin{tabular}{lrlllllll}
\hline \multicolumn{3}{c}{ Pf. Comp. Perf. } & \multicolumn{3}{c}{ Impf. Comp. Perf. } & \multicolumn{3}{c}{ Totals } \\
\hline No Aux: & 131 & $(72 \%)$ & No Aux: & 47 & $(72 \%)$ & No Aux: & 178 & $(72 \%)$ \\
Aux: & 50 & $(28 \%)$ & Aux: & 18 & $(28 \%)$ & Aux: & 68 & $(28 \%)$ \\
Total: & 181 & $(100 \%)$ & Total: & 65 & $(100 \%)$ & Total: & 246 & $(100 \%)$ \\
\hline \hline
\end{tabular}

NB: there are a total of $5 \mathrm{pf}$ aorists and $50 \mathrm{impf}$ imperfects in the text. 
Table 6. Auxiliation of 3rd-person L-Participles in $L A E$, by Aspect

\begin{tabular}{lrrllllll}
\hline \multicolumn{3}{c}{ Pf. Comp. Perf. } & \multicolumn{3}{c}{ Impf. Comp. Perf. } & \multicolumn{3}{c}{ Totals } \\
\hline No Aux: & 208 & $(88 \%)$ & No Aux: & 44 & $(79 \%)$ & No Aux: & 252 & $(86 \%)$ \\
Aux: & 28 & $(12 \%)$ & Aux: & 12 & $(21 \%)$ & Aux: & 40 & $(14 \%)$ \\
Total: & 236 & $(100 \%)$ & Total: & 56 & $(100 \%)$ & Total: & 292 & $(100 \%)$ \\
\hline \hline
\end{tabular}

NB: there are a total of $10 \mathrm{pf}$ aorists and $22 \mathrm{impf}$ imperfects in the text.

Tables 5 and 6 show that the ratio of auxiliated pf $l$-participles to unauxiliated pf $l$-participles is higher in Asen than in $L A E$, and a chisquare test shows that the difference between these ratios is statistically significant $\left(\chi\right.$-squared $=15.7, \mathrm{df}=1, \mathrm{p}$-value $\left.=7.37^{\mathrm{e}-05}\right)$. Though the effect size is not large, it is reportable (0.19), and in my view this is to be expected with phenomena that are based on alternate subjective construals. On the other hand, the difference between the ratios of $\mathrm{pf}$ aorists to pf compound perfect forms in the two texts is not statistically significant. Neither is the difference between the ratios of auxiliated to unauxiliated impf $l$-participles. The relatively higher number of impf imperfects in Asen compared to $L A E$ is statistically significant ( $\chi$ squared $=4, \mathrm{df}=1, \mathrm{p}$-value $=0.045)$, with a smaller effect size $(0.14)$. Not only does Asen contain a higher number of imperfect forms overall, but it also attests imperfect forms of a greater variety of lexical verbs, which suggests that the imperfect tense was used actively by the translator.

The statistically significant difference between the ratios of auxiliated pf $l$-participles to unauxiliated pf $l$-participles indicates that $A s e n$ is slightly more conservative than $L A E$ in retaining third-person perfect auxiliaries. The fact that Asen contains a relatively high number of impf imperfect forms and a relatively low number of unauxiliated pf $l$ participles, whereas $L A E$ contains a low number of impf imperfects and a high number of unauxiliated pf $l$-participles, can (if we take the higher number of imperfects in Asen at face value), be interpreted as an indication that unauxiliated third-person l-participles entered the language in pf verbs and that it was the narrative function of the pf (foregrounded, sequenced events) that initially triggered auxiliary drop. 


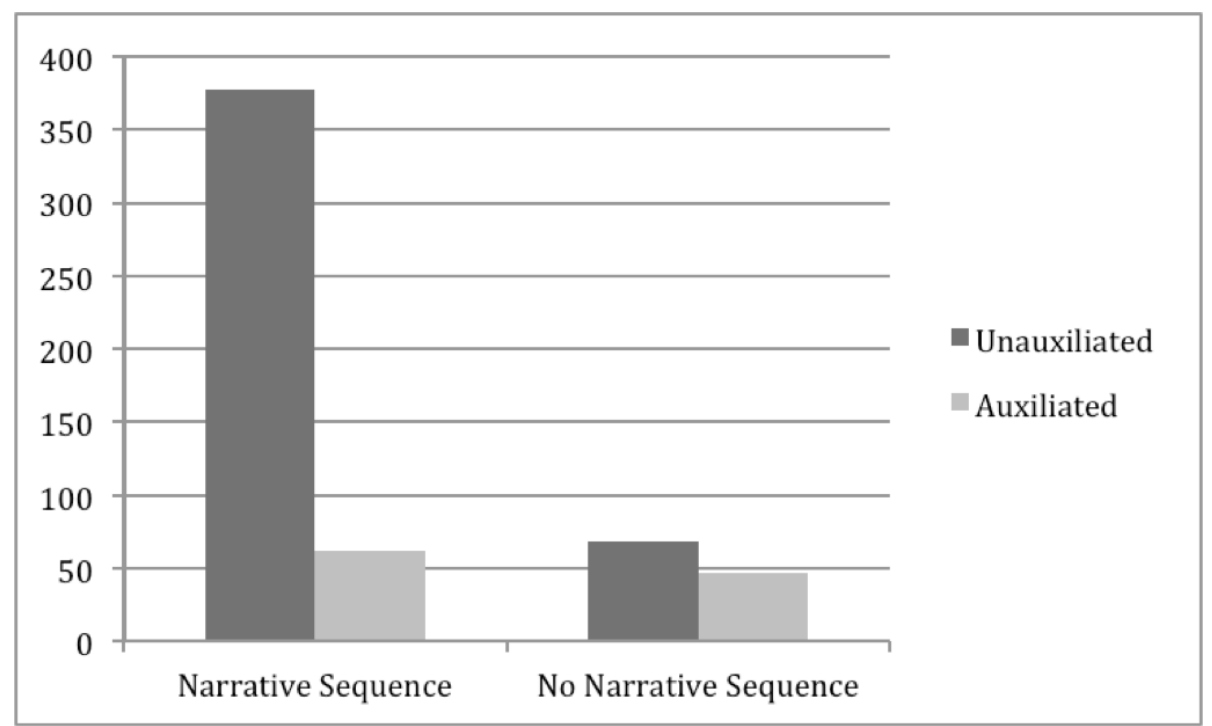

Figure 4. Auxiliation of 3rd-Person L-Participles in Asen and LAE with Regard to Narrative Sequencing, in terms of Tokens

This brings us to the difference between auxiliated and unauxiliated $l$-participles in the third person. Tables 5 and 6 showed that $l$ participles do occur in the third person with the auxiliary. Figure 4 shows the breakdown according to whether the verb form occurs in a narrative sequence of events. Clearly, unauxiliated forms predominate in contexts of narrative sequences $(\chi$-squared $=39.6, \mathrm{df}=1, \mathrm{p}$-value $=$ $3.2^{\mathrm{e}-10}$, but both auxiliated and unauxiliated forms occur in narrative sequences and in other contexts, which is why the effect size is moderate (0.27).

The conservatism of Asen compared to $L A E$ regarding auxiliary drop appears to confirm the relevance of narrative sequencing as a factor resulting in auxiliary drop. This can be seen in the graphs in Figures 5 and 6 , which give the percentages of auxiliated and unauxiliated third-person perfects with regard to narrative sequencing in each text. 


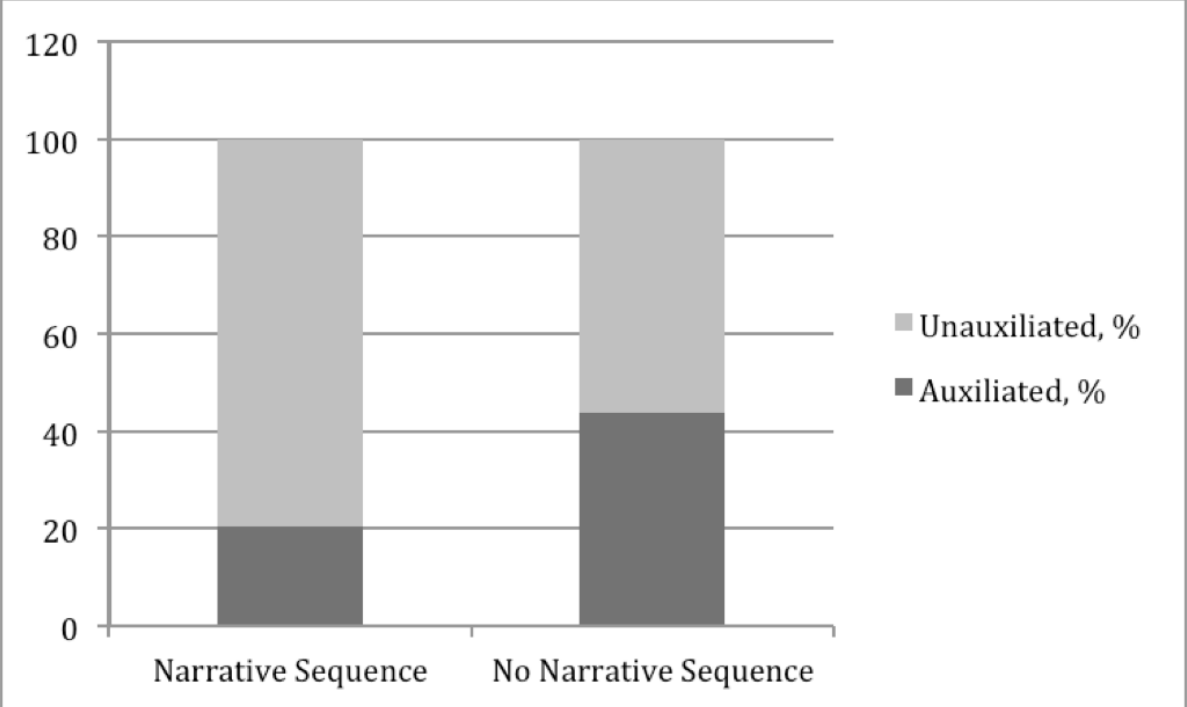

Figure 5. Auxiliation of 3rd-Person L-Participles in Asen with Regard to Narrative Sequencing, by Percentage

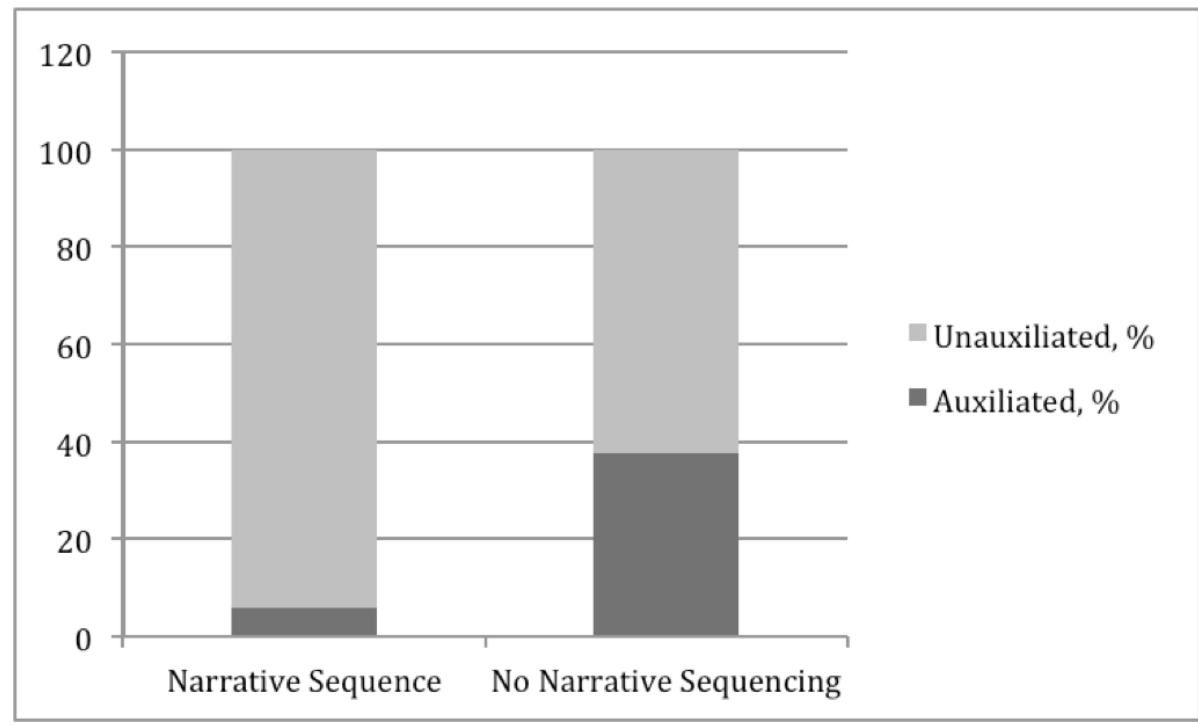

Figure 6. Auxiliation of 3rd-Person L-Participles in $L A E$ with Regard to Narrative Sequencing, by Percentage 
It should be pointed out here that the difference between the ratios of auxiliated to unauxiliated $l$-participles in contexts without narrative sequencing is not statistically significant $(\chi$-squared $=0.34, \mathrm{df}=1, \mathrm{p}$ value $=0.56$ ). The difference in the ratios of auxiliated to unauxiliated $l$-participles in contexts with narrative sequencing on the other hand is statistically significant $(\chi$-squared $=10.6, \mathrm{df}=1, \mathrm{p}$-value $=0.001)$. These facts taken together strongly suggest that $L A E$ is more sensitive than Asen to narrative sequencing as a criterion for third-person auxiliary drop.

A final piece of evidence for the overall relevance of narrative sequencing for auxiliary variation is a random forest statistical analysis that was run on the combined tokens of Asen and $L A E$ to determine the most important variable influencing variation in third-person auxiliation; this is given in Figure 7 on the next page. ${ }^{11}$ The dot plot shows that narrative sequencing is far and away the most important variable affecting coding, followed by aspect (the latter probably due not only to the relatively high numbers of unauxiliated pf third-person l-participles in $L A E$ but also to the relatively high numbers of impf imperfects in the two texts).

Before turning to the issue of the meaning of the auxiliated thirdperson $l$-participles, I should point out that though the direct speech in $L A E$ tends to contain simple statements of fact as opposed to narration, the latter does occur in direct speech, so that there is no simple division between narrative sequencing and direct speech. ${ }^{12}$ An example of narration in direct speech is given in (6):

(6) A když sem se tak pánu bohu modlil, ihned svatý Michal uchopil mě za ruku, i nesl mě do ráje navštievenie a viděnie božieho.

'And when I was thus praying to the Lord God, straightway Saint Michael grabbed me by the arm and carried me to the paradise of the presence and sight of God.'

\footnotetext{
${ }^{11}$ A random forest analysis is a statistical method that constructs a number of classification trees by randomly selecting not only data samples but also predictor variables in each split of each tree. For details, see Strobl, Malley, and Tutz 2009.

12 Asen contains almost no direct discourse and no tokens of the compound perfect in direct discourse, so the relevant data is limited to $L A E$.
} 


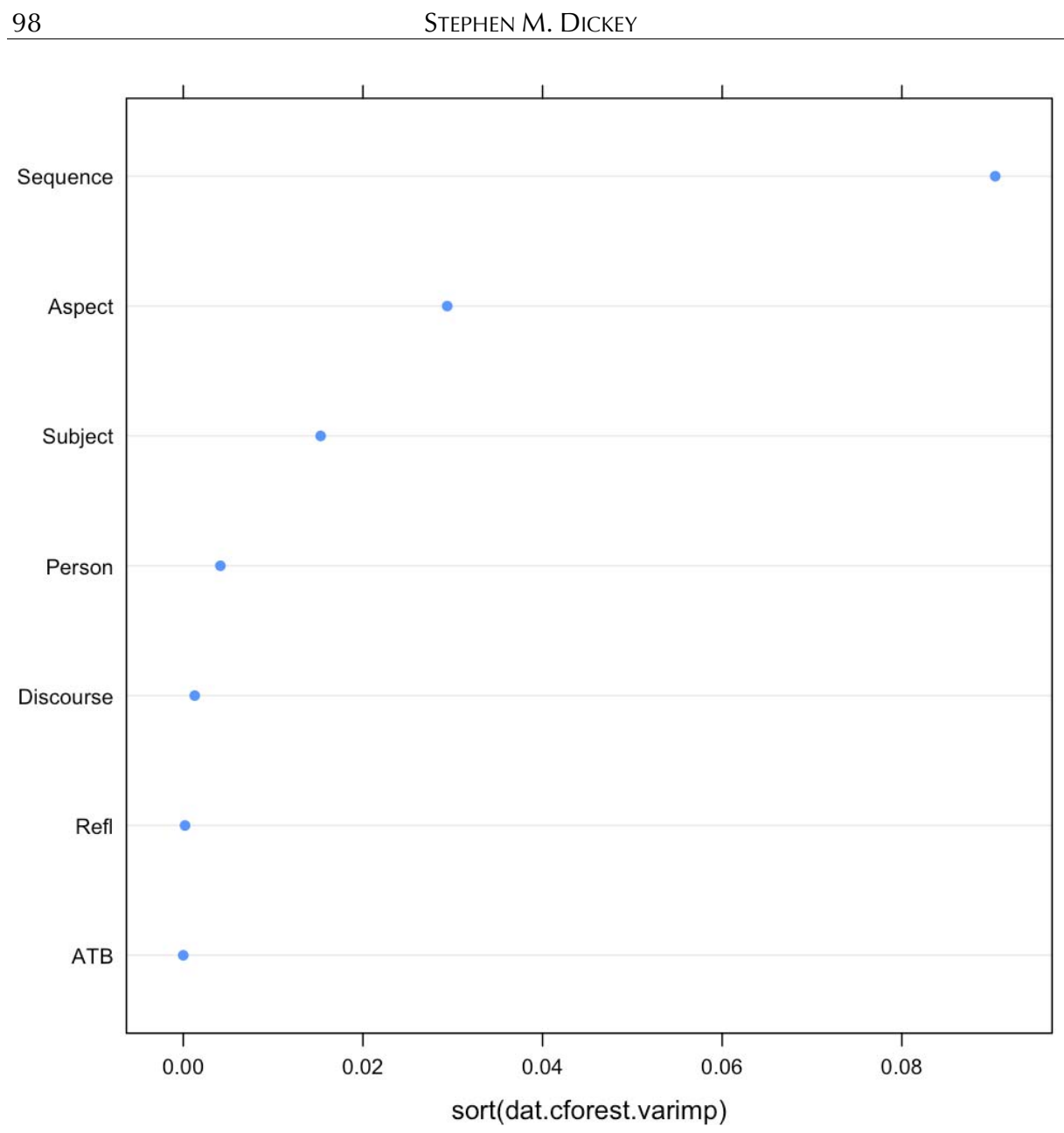

Figure 7. Dot Plot of the Relative Importance of Variables Influencing 3rd-Person Auxiliary Variation in Asen and LAE

Thus, the distribution of auxiliated $l$-participles shows $l$-participles occurring in the expression of some kind of perfect meaning, whether in direct speech or in the main narrative line. In the relatively few passages containing direct speech, the perfect meaning is common, as some single event is presented as having a result that is relevant at the time of the discourse, as shown in the examples in (7). 
(7) a. Tot jest dal pán buoh zvieřatóm a hovadóm zemským $\mathrm{k}$ jedení, ale náš pokrm bieše anjelský.

(LAE: 295)

'The Lord God AUX gave [has given] this to the beasts and earthly animals to eat, but our food was angelic.' [Said in the presence of the food given to the animals.]

b. Vstaň od těla otce tvého a pod' sem, aby vid’al otce tvého, co jest $\mathrm{s}$ ním učinil buoh.

'Arise from the body of your father and come here to see your father, what God AUX did [has done] with him.'

In addition to cases that are identifiable as prototypical instances of the perfect in direct speech, auxiliated third-person l-participles appear to occur in mini-narratives in direct speech to mark highly important or remarkable events. I assume that the coding of highly important events in narratives is a secondary function of auxiliated third-person $l$-participles, that of emphasis. A clear example is given in (8). ${ }^{13}$

(8) Když odešli byli andělé boží, hned d’abel přistupiv, i svedl matku vaši a řekl jie, aby jedla $\mathrm{z}$ dřeva zapověděného. I jedla jest a dala mně také.

'When God's angels had left, the devil stepped in straightaway, and beguiled your mother and told her to eat from the forbidden tree. And she ate AUX and gave to me also.'

Note that such highly important events also lend themselves to a perfect interpretation, even if they are unlikely to be translated with perfects in English. That is to say, it is not clear that the hypothesized emphatic function of auxiliated l-participles in the expression of important events is necessarily distinct from the expression of current relevance in cases that are more recognizably "perfect." Further, if the reference point of the compound preterit at this time is the speaker's experiential domain as suggested in section 2.2, then it makes sense that events that are construed as particularly important or noteworthy in the domain of the speaker's experience would be eligible for auxiliation.

\footnotetext{
${ }^{13}$ Given the single agent and the conjoined clauses, I consider dala 'gave' to be auxiliated with jest as well; this is an example of across-the-board auxiliation.
} 
Another likely example of an important event is given in (9), from Asen.

(9) A v tej chvíli Apis, král arginský, v Ejiptě chrám jest udělal.

(Asen: 340)

'And in this time Apis, the Argeian king, AUX built a temple in Egypt.'

This sentence ends a section of the narrative and there is no further comment. I assume that the chronicle-esque inclusion of an event of this kind reflects a view that it was an important event in some way, if only because of the magnitude of the endeavor.

Stative impf verbs occur with auxiliaries three times in the main narrative as well. They are arguably also emphatic, as they refer to the extremely old ages of the characters (twice) and a high number of offspring (once), as shown in the examples in (10).

(10) a. I on také umřel jest, když jest byl sto a ve dvatceti letech v stáři $[\ldots]$

'And he [Joseph] died, when he AUX was one hundred and twenty years of age [...]'

b. A po porození Setovu Adam byl jest živ devět set let a čtyřidceti let a měl jest čtyřidceti synóv a čtyřidceti dcer kromě Kaina a Ábele a Seta.

'And after the birth of Seth Adam was AUX alive nine hundred and forty years and had AUX forty sons and forty daughters besides Cain and Abel and Seth.'

The mythically high ages and high numbers of children provide circumstantial evidence that the auxiliated $l$-participles in (10) are emphatic, even though they are stative impf predicates and as such ineligible to be foreground.

The hypothesized functions of a perfect construal and emphasis are related, in that the perfect construal involves an emphasis on an event as having consequences at the time of speech. The two functions may be viewed as being in a family-resemblance relationship: as just pointed out, most perfects are also arguably emphatic, and then there are cases of emphasis as in examples (8-9) that are not perfect. Again, 
if the reference point of the compound perfect at this time is the speaker's experiential domain, it makes sense that events that are construed as particularly important or noteworthy in the domain of the speaker's experience should be eligible for auxiliation, even if they have no direct result that would make them canonical cases of the perfect. Comparative evidence for a connection between the perfect and emphasis is also the fact that in Polish the third-person auxiliaries became person-neutral markers of emphasis for a time, as pointed out in section 1.

Finally, it is worth pointing out that in both Asen and LAE auxiliated third-person $l$-participles in the main narrative line occur occasionally to express the past perfect, as shown in (11). ${ }^{14}$

(11) a. Ti zdvihši syna Faraonova od země, umyli sú ránu jeho a pověděli sú tyto všecky věci Faraonovi, a on poděkovav jim, že sú nezabili jeho.

(Asen: 347)

'Those men lifted Pharoah's son from the ground, washed AUX his wound and told AUX all these things to Pharoah, and he thanked them because they AUX not killed [had not killed] him.'

b. Potom pak, když jsú obětovali pánu bohu oběti, zabil Kain

Ábele.

$(L A E, 300)$

'But later, when they AUX offered [had offered] their offerings to the Lord God, Cain killed Abel.'

The minor past-perfect use of auxiliated third-person l-participles supports the hypothesis that in the fourteenth century these verb forms express a kind of perfect in contrast to unauxiliated third-person $l$ participles.

To sum up, this section has presented evidence that in fourteenthcentury Czech narratives auxiliary variation with third-person l-participles expressed a semantic distinction, that between a perfect and/or emphatic meaning (auxiliated third-person $l$-participles) and a neutral narrative preterit (unauxiliated third-person $l$-participles). Based on this evidence, I conclude that auxiliation coded an aspectual distinction in Old Czech as late as the end of the fourteenth century. The next

${ }^{14} \mathrm{Cf}$. the real past perfect odešli byli 'had gone' in example (8). 
section complements the narrative data from Asen and $L A E$ with private correspondence into the early seventeenth century.

\subsection{Letters from 1365 to 1615: Old Epistolary Texts of Czech Wives and Daughters}

In order to help determine whether the semantic distinction expressed by auxiliation was a real part of Old and Middle Czech grammar or just a stylistic feature of conservative narrative texts, a second data set was examined, consisting of letters written by or to Czech women from 1365 to 1615. My data set comprises the third-person past-tense verb forms in the first 196 letters contained in Old Epistolary Texts of Czech Wives and Daughters (Staré písemné památky žen a dcer českých; henceforth Letters 1365-1615). The data from the letters end in 1615, as by this time auxiliation is very infrequent, and the year 1615 provided a convenient cut-off point. ${ }^{15}$

Before proceeding, some comments on the source for the second data set is in order. The authors of the letters in question appear to have been mostly upper-class Czech women. However, men are also well represented: writers of 45 of the 116 letters in question were men. Thus, the possibility of a gender effect seems unlikely, as I could not detect any differences in auxiliation between the letters written by men versus those written by women. Regarding the socio-economic class of the writers, they may have changed over the three centuries covered by the letters, but a lack of accessible information on them renders any distinction(s) in this regard impossible. In any case, all the letters seem to have been written by people who were either nobility or affluent to some degree. As for the textual character of the letters, they vary from public correspondence (e.g., letters including affidavits and petitions) to private business correspondence and personal correspondence, and sometimes the latter two types occur in one and the same letter. Naturally, the letters as a whole are primarily discursive, in contrast to the narratives of Asen and $L A E$. Further, regardless of the particular type of correspondence of a given letter, they seem to be fairly conversational and not overly formal, apart from certain legal phrases, forms of address, and individual lexical items relating to finance, e.g., $d s k a$ for

\footnotetext{
${ }^{15}$ Additional data show that by 1620 there were almost no instances of auxiliation of third-person $l$-participles whatsoever.
} 
deska 'register'. Thus, I see no reason not to consider the data contained in these letters as basically representative of real Czech usage of the time. Further, it is worth pointing out that the system of auxiliation in these letters appears to correspond to that of other correspondence and texts of a non-literary type for the time period under consideration that I have studied since compiling the data for Letters 1365-1615 (in this regard, see fn. 17).

There are 507 tokens of third-person $l$-participles in the data set of the letters. The number of tokens for a given year increases as time goes on due to the higher number of letters preserved. Each token was described for the following parameters: (i) auxiliation (auxiliated vs. unauxiliated), (ii) aspect (perfective vs. imperfective), (iii) subject (overt subject vs. no overt subject), (iv) number (singular vs. plural), (v) temporal localization (presence vs. absence of a temporal adverb and/or a context of narrative sequencing), (vi) spatial adverb (presence vs. absence of spatial adverb), (vii) relative clause (occurrence vs. nonoccurrence in a relative clause), and (viii) reflexivity (reflexive vs. nonreflexive). These parameters differ slightly from those used for Asen and $L A E$; this is due to the different nature of the letters.

Unlike the data for Asen and LAE, the data for Letters 1365-1615 provide not only abundant information about direct discourse (as reflected in public and private correspondence) but also a diachronic sample of usage over a 250-year period, though the data is relatively limited for the early years (1365 to around 1425). Thus, this data set allows for an investigation of auxiliary variation through time, basically until the complete elimination of auxiliaries from third-person forms of the compound preterit. In these letters the auxiliation of third-person l-participles drops fairly sharply over the 1590s and as pointed out above auxiliaries had basically disappeared from thirdperson active past-tense forms by 1620 . The overall trend of auxiliation of third-person l-participles is shown in the generalized additive model (GAM) plot in Figure 8. ${ }^{16}$

\footnotetext{
${ }^{16}$ I am grateful to Harald Baayen for running the GAM analysis and providing the plot in Figure 8.
} 


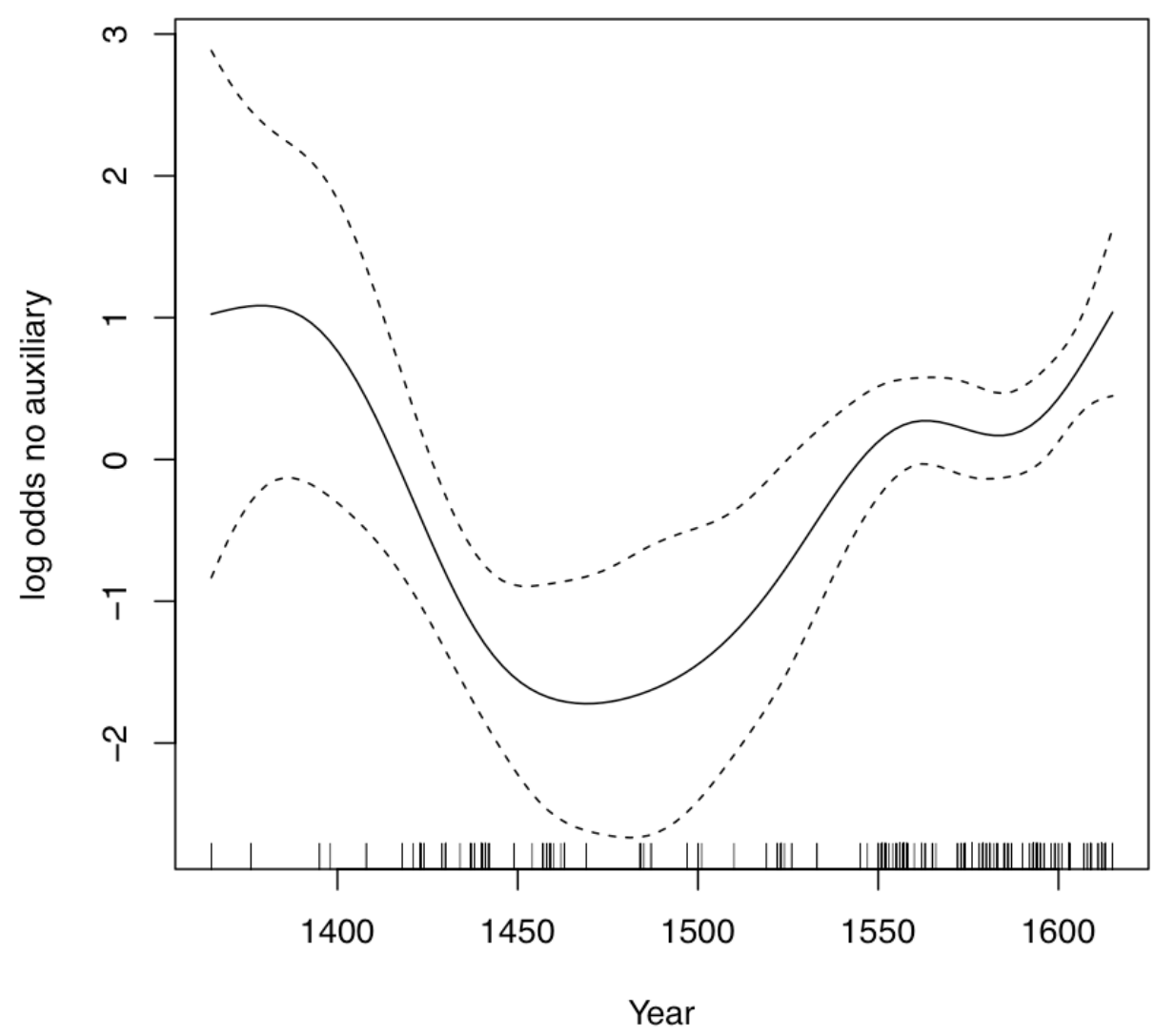

Figure 8. GAM Plot of Auxiliation of 3rd-Person

L-Participles in Letters 1365-1615

In Figure 8, zero on the $y$-axis represents an equal probability of auxiliation or no auxiliation. The negative numbers represent increasing probabilities of auxiliation, and the positive numbers represent increasing probabilities of no auxilaition. Thus, the upward curve indicates a progressively higher probability of no auxiliation as time goes on after around 1470. The dotted lines represent a 95\% confidence interval, which is so large in the earliest period (to about 1425) that this part of the curve is unreliable. A full account of the loss of the thirdperson auxiliaries in this period is quite complex and involves many factors, including the development of auxiliation of the past passive construction (not shown in Figure 8), and therefore cannot be at- 
tempted here. In what follows I focus on the feature of temporal localization as a predictor of unaxiliated third-person $l$-participles.

Despite the changes in auxiliation through time that culminate in the elimination of the third-person auxiliaries from the compound preterit, temporal localization is the most important variable affecting auxiliary variation throughout the period under investigation. This is clear from the dot plot of the random forest analysis for the importance of the variables in this data set given in Figure 9.

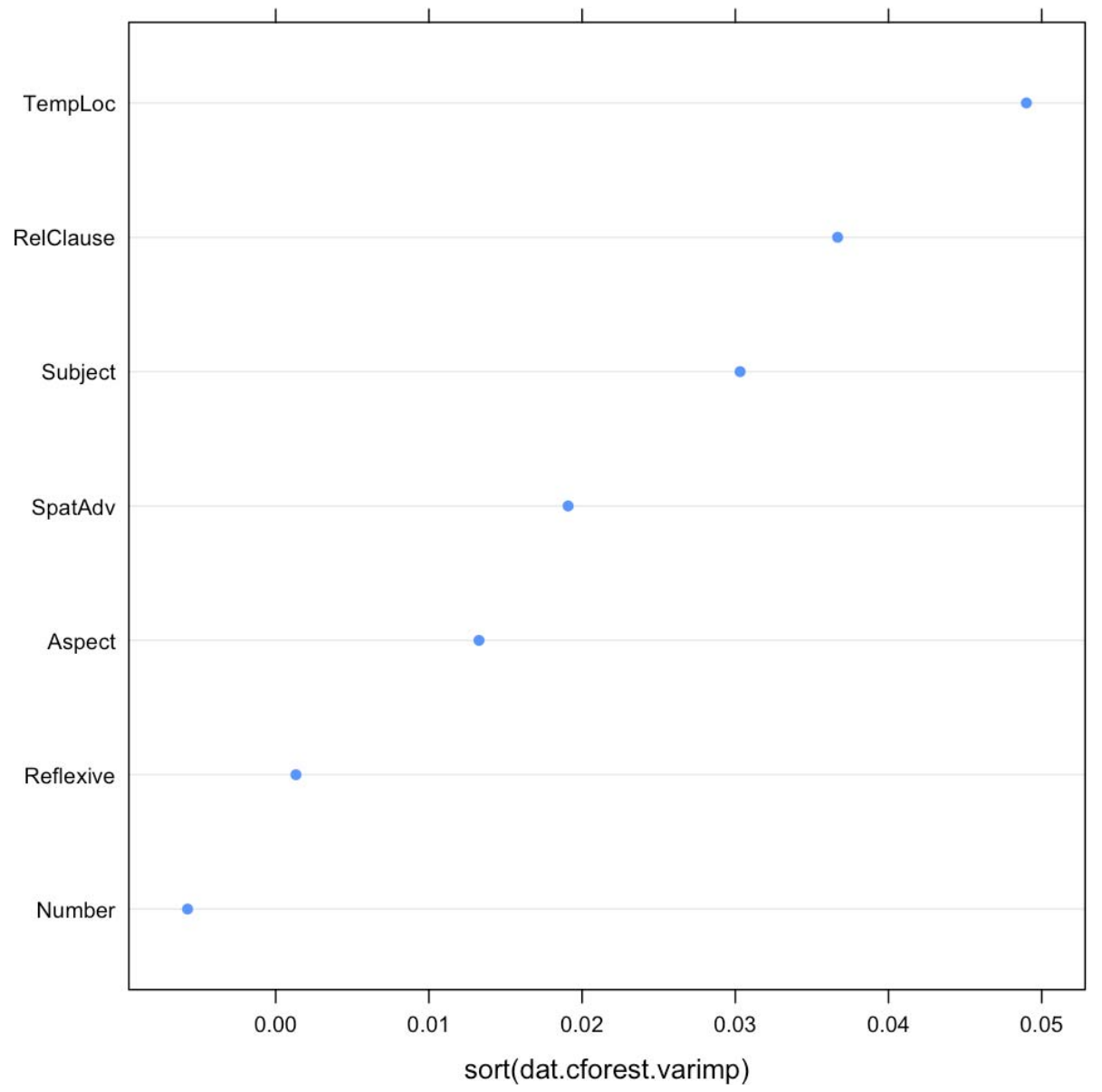

Figure 9. Dot Plot of Relative Importance of Variables Influencing Auxiliary Variation with 3rd-Person L-Participles in Letters 1365-1615 
Temporal location is the most important variable in that the presence of temporal location increases the probability of auxiliary drop. Examples of unauxiliated $l$-participles in contexts of temporal location are given in (12); (12a-b) contain temporal adverbs, (12c) contains a temporal adverb and a sequence of events, and (12d) a sequence of events.

(12) a. [...] a ty penieze hned mi je všecky dal a zaplatil hotovými penězi.

'[...] and all that money he immediately gave it [lit., them] to me and paid in cash.'

b. Včera přišlo mi psaní od V. M. z Prahy, v kterémž mi psáti račte, že na svém zdraví dobře míti račte;

'Yesterday a letter came to me from Your Grace, in which you deign to write to me that you are in good health;'

c. [...] že když jsme přijeli do Lún města, tehdy přistúpivše před nás paní Anna manželka Václava řečeného Škrofa $z$ Lún, Vičen z Dobroměřic, Kúbek někdy líhovník v Lúnech a Macek z Dobroměřic, i seznali před námi k svému svědomí [...]

(1437; SPP: 29)

'[...] that when we arrived in Louny, then Lady Anna, wife of Václav aka Škrof of Louny, Vičen of Dobroměřice, Kúbek, formerly a cooper in Louny and Macek of of Dobroměřice, having come before us, unanimously confirmed their testimony $[\ldots]^{\prime}$

d. Já Oldřich z Rosenberga, vyznávám tiemto listem všem, ktož jej čísti neb čtúce slyšeti budú, že paní Margreta, někdy manželka Čeňkova z Dúdleb, přišla před mě a vyznala, že všecko své věnné právo, kteréž jest měla na dědinách ve vsech Dúdlebiech, v Hórce, v Strakonicích i jinde, kdež co má, jakožto plněji ve dskách zemských psáno stojí, a k tomu, což jest jejie muž měl, to jest přede mnú a před mnoho dobrými, slovútnému panoši Petrovi Svatomirovi z Hórky vzdala, a žádného sobě práva na tom ne zuostavila.

(1423; SPP: 17)

'I Oldřich of Rosenberg affirm with this letter to everyone who might read or hear it read, that Lady Margreta, 
formerly the spouse of Čeněk of Doudlebi, came before me and affirmed that all her marital claims, which she has had to estates in the villages of Doudlebi, in Hórka, in Strakonice and elsewhere, wherever she has anything, as is stated more fully in the land registers, and in addition, whatever her husband had, these she has ceded before me and before many other good people to the celebrated nobleman Petr Svatimirov of Hórka, and retained no claim thereto for herself.'

Temporal adverbs appear to be slightly more important for conditioning the unauxiliated forms than simple event sequencing, as limited sequences do occur in a perfect construal, as shown in (13). It is possible that the auxiliated forms in this example are used to express emphasis.

(13) Vznesl jest na nás slovútný Václav z Klokočky, najvyšší hejtman náš věrný milý, že byste jemu syna jeho jali, i slíbil jest on za to před námi, že má před námi anebo před J. M. státi, a z čehož mu kto vinu dá, že každému ze všeho má prav býti.

(1469; SPP: 56)

'The celebrated Václav of Klokočka, our loyal, dear, highest captain has submitted to us that you adbucted his son, and has sworn before us that he is to stand before us or before Your Grace, and if anyone accuses him of anything, that he should be blameless to anyone concerning the whole affair.'

In any case, it is worth noting that (12c) presents the initial sequence with unauxiliated l-participles, whereas when the speaker later presents the upshot of Lady Margreta's waiver outside of a sequence of events, he switches to the auxiliated l-participle jest... vzdala 'has ceded'.

The lack of auxiliation in contexts of temporal localization (i.e., temporal adverbs and sequencing) suggests that Letters 1365-1615 share the same basic system of third-person auxiliary variation described for Asen and $L A E$, i.e., that unauxiliated third-person l-participles are a neutral preterit, whereas auxiliation signals a perfect construal and/or emphasis. An example of unauxiliated $l$-participles in a context containing temporal adverbs and sequencing is given in (14a) 
and an example showing a perfect construal expressed by auxiliation is given in $(14 b-c)$.

(14) a. Pan Činispán umřel i s manželku svú; v pátek se rozstonala a v pondělí ji pochovali na Rožmberce, a on se po ní třetí den rozstonal, i dal se nemocný na Krumlov přivézti ve čtvrtek večer; v neděli udělal všicku správu křestanskú, v noci na pondělí umřel.

(1552: SPP: 81)

'Mr. Činispán died with his wife, too; on Friday she started ailing and they buried her in Rožmberk on Monday, and three days after her he started ailing and had himself driven to Krumlov on Thursday evening; on Sunday he received his last rites, and in the night from Sunday to Monday he died.'

b. a tak jest již k tomu přišlo, že málo jich vokolo všeho rynku, kteří by při víře křest’anské zůstali;

(1551; SPP: 80)

'and so it AUX already come to the point where there are few around the whole square that would remain by the Christian faith;'

c. Jindřich s svými prrátely se jest postavil, tak jakož na poslušného záleží, ale vy se k ničemu nemáte,

(1497; SPP: 62)

'Jindřich AUX made himself available with his kin, as befits an obedient man, but you are doing nothing of the sort,'

These are only representative examples, and many more could be adduced (cf. also examples (16-17) in section 4$).{ }^{17}$

\footnotetext{
${ }^{17}$ Regarding the issue of the reality of the system evident in Letters 1365-1615, I should point out that other non-literary sources from the same time period that I have examined (although not statistically) since this investigation show similar patterns of usage. For instance, Kabátnik's Journey from Bohemia to Jerusalem and Egypt of 1491-1492 (Cesta $z$ Čech do Jeruzaléma a Egypta $r$. 1491-1492) contains very many unauxiliated forms that narrate events, whereas events whose results are stressed as being currently present are coded by auxiliated forms, as shown in (i-ii).

(i) Jakož sem jednoho viděl i znal, kterýžto při tom času, když sem tam byl, dal se obřezati a přijal vieru jich; (early 16th cent.; CČJE) 'As I saw and knew one man, who while I was there, had himself circumcized and accepted their faith;
} 
Let us now turn to the relation between temporal location and the ultimate demise of the auxiliary. Figure 10 gives a breakdown of thirdperson auxiliary variation according to temporal location, by percentage. With the exception of the first period (1365-1415), I chose to break down the graph into periods of forty years to ensure enough data in a given period while at the same time providing the maximum possible number of periods. If we exclude the first period, for which the data are very limited, the percentages may be interpreted as indicating that the unauxiliated third-person l-participle begins to take over as a general preterit form in the latter half of the sixteenth century. This is the time when the unauxiliated l-participle begins to be used more frequently than the auxiliated l-participle in contexts lacking temporal location, i.e., contexts that correlate with a perfect construal. In other words, we may interpret the decreasing correlation between unauxil-

(ii) I pravili sme jemu skrze tlumače, kterak jest nám ten zlý člověk učinil neprávie.

(early 16th cent.; CČJE)

'And we told him through an interpreted how that wicked man AUx [had]

done us an injustice.'

Note that in (ii) the past perfect in English is due to its sequence of tenses rule: the reported speech had a current result at the speech time.

Likewise, other letters show the same patterns of usage, as shown in (iii), in which the arrival of the information has a current result and the $l$-participle is thus auxiliated, whereas the actions of the horsemen, the results of which are not immediately present to the writer, are expressed by unauxiliated forms:

(iii) Wězte, že jest nás w prawdě došlo, kterak nyní někteří raitaři a swéwolní zlí lidé sebrawše se silně na poddané naše w Morawě a w Slezí nepřátelsky sáhli, biskupu a kostelu Wratislawskému městečko jmenem Feynwald wypálili, dobytky i jiné wěci pobrali [...]

(1505; AČČSPP: 326)

'Know, that [news] AUX indeed reached us, that recently some horsemen and headstrong, wicked men, having assembled in great numbers, descended on our subjects in Moravia and Silesia in a hostile manner, burned a town by the name of Feynwald belonging to the bishop and diocese of Wrocław, carried off property and other things $[\ldots]^{\prime}$

Many more examples from these and other texts could be adduced. Given that other texts from the same period appear to express the same distinction by auxiliary variation, we are justified in concluding that the system evident in Letters 1365-1615 was a real part of Old and Middle Czech grammar. As a last point it is worth mentioning that Kabátník's travelogue was dictated to his assistant, which suggests that the auxiliary usage contained in it was part of spoken usage patterns of the time. 


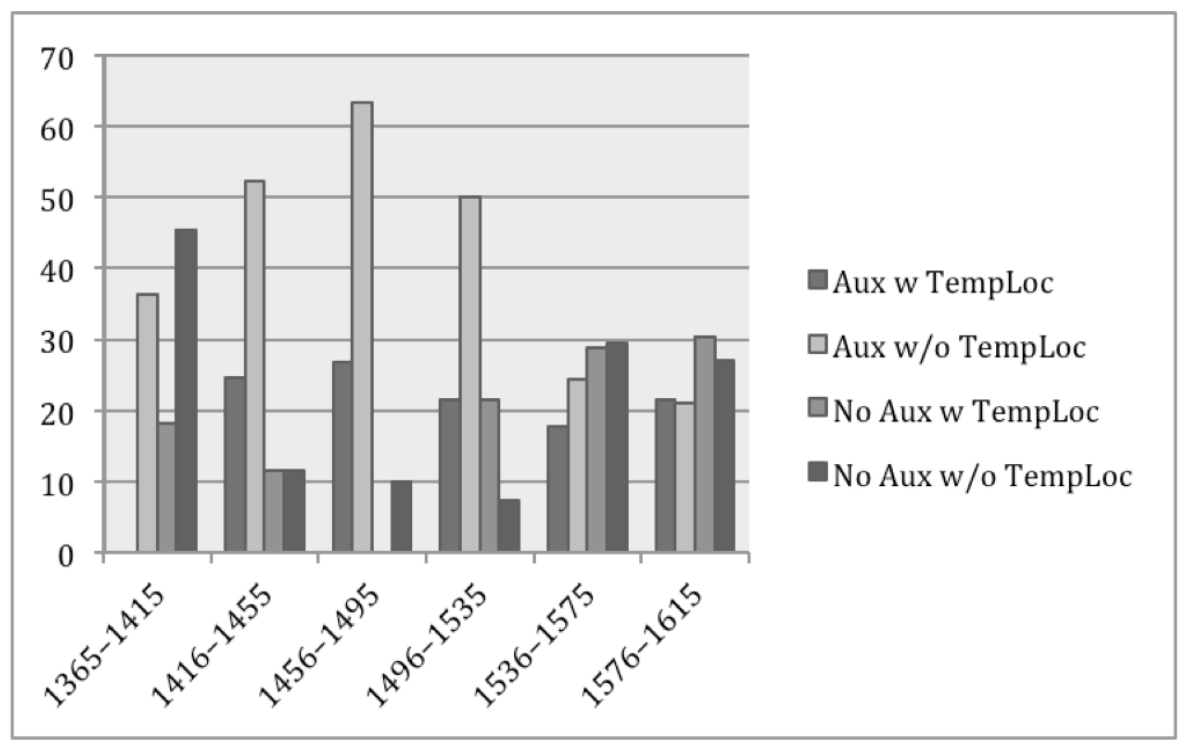

Figure 10. Breakdown of the Auxiliation of 3rd-Person L-Participles According to Temporal Location, in Percentages

iated third-person $l$-participles and contexts including indicators of temporal location as an indication that the auxiliary is losing its perfect function of current relevance. Thus, the old semantic system appears to be breaking down (as indicated by the more equal shares of auxiliation vs. non-auxiliation according to the presence vs. absence of indicators of temporal location) in the latter half of the sixteenth century, which makes sense as the stage immediately preceding the total loss of third-person auxiliaries (by around 1620). It is possible that prior to the final loss the function of auxiliaries passed through a stage where they did not express the current relevance of the perfect but expressed emphasis more generally.

This discussion of auxiliary variation in Letters 1365-1615 has been brief due to limitations on space. There is much to say about other variables, especially the parameter for relative clauses, which are correlated with auxiliation to a significant extent. ${ }^{18}$ Moreover, the complete

\footnotetext{
18 This relationship was an unexpected finding of the statistical analysis that was made for this investigation. Without going into detail, however, I think that relative clauses, which typically provide more information about various discourse entities, are in-
} 
story of the loss of third person auxiliaries must treat the contrasting increase in the auxiliation of third-person past passive participial constructions, ${ }^{19}$ which cannot be undertaken here. Nevertheless, the evidence presented above indicates that the distinction between current relevance/emphasis and neutral past-tense narration established for the late fourteenth-century narrative texts Asen and $L A E$ continued to exist in some form in discursive textual usage for roughly the next 150 years. Section 4 briefly considers the significance of this finding for the history of Slavic verbal aspect.

\section{Relevance for a Comparative Diachronic Analysis of Slavic Aspect}

The previous sections have argued that despite the substantial reduction of use of the aorist and imperfect by the end of the fourteenth century, a distinction reminiscent of the opposition between the aorist and the compound perfect in Common Slavic and Old Czech was preserved in the third person of the new Czech compound preterit into the latter half of the sixteenth century. In contrast, recall that as discussed in section 1 Russian lost both its aorist and imperfect and its third-person auxiliaries in the compound preterit much earlier, by the eleventh century in northern dialects. Thus, from the eleventh century to the late sixteenth century (or much of this period, depending on the dialect of Russian) there was a significant difference in the past-tense

cluded in the letters when they are directly relevant to the speakers' present concerns, i.e., they are likely to involve a perfect construal. In this regard, it is worth pointing out that the elaborative character of relative clauses makes them background material, and Ming (2010: 43) has pointed out the unacceptability of perfective/foregrounding le and the contrasting acceptability of experiential (perfect)/backgrounding guo in Mandarin Chinese relative clauses. If we treat Old and Middle Czech unauxiliated l-participles as largely corresponding to foreground, and auxiliated $l$-participles as largely corresponding to background (except in cases of emphasis), then the tendency for auxiliated forms to occur in relative clauses makes more sense. And inasmuch as the tendencies of auxiliation in Old and Middle Czech correspond to what is known about modern languages such as Chinese, it seems more likely that it was expressing a construal as opposed to being an artificial stylistic feature of certain registers.

${ }^{19}$ Asen and $L A E$ attest numerous instances of unauxiliated third-person participial passives, e.g., a položen $v$ škřini 'and he was put into the coffin'. These refer to narrated events and this function contrasts with the perfect function of auxiliated third-person participial constructions, e.g., jméno tvé napsáno jest 'your name has been written down'. 
systems of the two languages: aspectual distinctions were not expressed by competing past-tense forms in Russian, whereas in Czech auxiliation in the past tense expressed a distinction between the perfect/emphatic construal and a neutral past-tense construal. The distinction was limited to the third person, but this is nevertheless no small difference between the two languages, because the alternative aspectual construals at issue here are at least as important in the third person as they are in the second person (and probably first person as well).

This difference can help explain the absence in Old and Middle Czech of some impf usage that is attested in Old Russian as early as the twelfth century. In particular, Russian attests the so-called twoway use of impf verbs from this time, as shown in the examples in (15).

(15) a. Ot sımъka kъ kulotъkě ože to jesi kazale nesъdě věveričı tixъ dělę koli to esi prixodile ${ }^{i} \mathrm{v}$ rus[ь] sъ lazъ(v)kъmъ tъgъdъ vъzęle $u$ mene lazъvke pereęslav[b]lě

(mid-12th cent.; Zaliznjak 2004: 356)

'From Sьmъk to Kulotъka, about what you said concerning that money, when you came to Rusb with Lazъvk, then Lazъvk took it from me in Perejaslavlı.'

b. Svědomo vamъ čto priězdilı ${ }^{i}$ zděse kъ namъ роръ Хaritonъ otъ vasъ sъ tovarišči na postavlenie: i my ixъ postavili, otpustili;

(1392-95; AI1: 17)

'You are aware that the priest Xariton came here to us from you with his colleagues for ordainment: and we ordained them and let them go;'

c. I Adam rek: "Davalom na to světъki, što esmi věščoe zaplatil, i tyi sud[ь]i světъkovъ moix ne prinjali." I my pytali Adama: "Estı u tebě na to spravu, što tyi sud[ь]i tvoe spravy ne prinjali, čeres toe tebě kovali i?" (15th cent.; PG II: 86)

'And Adam said: "For that I offered them evidence, [attesting] that I had paid the weighage, and those judges did not accept my evidence." And we asked Adam: "Do you have confirmation that those judges did not accept your evidence, in spite of which they put shackles on you?"' 
To be sure, the pf also occurs in questions and statements of fact involving annulled results in early East Slavic texts (cf. Dickey 2012), so that it seems most likely that such usage developed gradually, at different rates in different lexical groups of verbs and for different speakers. However, the most reasonable assumption is that such usage was the result of the collapse of the old past-tense system, as aspectual distinctions related to those of the old past-tense system developed in the newer and stable PF : IMPF opposition. In particular, it seems that the two-way use of impf verbs developed because the means to express the presence of a result at discourse time (i.e., the pf compound perfect) had completely merged with the means used to express narrative sequencing (i.e., the pf aorist) in the undifferentiated category of a general pf preterit. I cannot go into the details here, but I believe that the unification of the meaning of current relevance with that of narrative sequencing into a single abtract category was the first major step in the development of what I assume to be the current meaning of the eastern pf aspect, temporal definiteness (cf. Dickey 2000). The new two-way use of impf verbs was conditioned by the semantic development of the category of the pf in East Slavic, and may be simplistically characterized as means of coding the "absence of the relevant result of the event" in direct speech.

In contrast, I assume that the continued coding of alternative construals by auxiliary variation in Old and Middle Czech was an important factor reducing the likelihood of the development of such conceptual distinctions and usage types in its PF : IMPF opposition. In this respect, it is interesting that in Letters 1365-1615 the contrast between an existing result and its cancellation can be expressed by auxiliary variation, and is in any case not expressed by aspect. ${ }^{20}$ The absence of a result often coincides with a sequence of events, as in (16a-b), in which unauxiliated pf forms occur.

(16) a. Dnes posel z Krumlova přišel a ty stříbrné lžíce V. M. přinesl. Píše mi paní mátie, že jsou ve zdraví domů přijeli

\footnotetext{
${ }^{20}$ I have been unable to ascertain the two-way use of impf verbs in Old and Middle Czech texts, and it is very marginal in Modern Czech.
} 
všickni a oznamuje mi, že pan Míčan velmi těžce stůně, tak že mu již žádný netuší [...]

(1556; SPP: 90)

'Today an agent came from Krulov and brought to me those silver spoons of Your Grace's. Mother writes me that everyone AUX arrived [has arrived] home in good health and informs me that Mr. Míčan is gravely ill, so that no one can offer him any comfort now $[\ldots]^{\prime}$

(16) b. Dne včerejšího Jestřibský od V. M. přijel a psaní mi dodal, vedle toho i oustně zprávu dal, že již ve jméno Boží domů v dobrém zdraví jeti račte;

(1558; SPP: 102)

'Yesterday Jestřibský came from Your Grace and gave me the letter, and besides that verbally gave me the news that you have already decided to go home in good health in the name of the Lord;'

In contrast, currently existing results tend to be expressed by auxiliated pf forms even in the mid- to late sixteenth century, as shown in the second sentence of (16a), jsou ve zdravi domü prijeli 'have arrived home in good health', and (17a-c).

(17) a. Služebnik tvůj ten jest sem dnes večer i s doktorem Kunštatem přijel, a že jsi ho sem poslal, velice tu děkuji;

(1554; SPP: 84)

'Your servant, he AUX arrived [has arrived] here this evening and with Doctor Kunštat, and I thank you very much for having sent him.'

b. V. M. prosím, račte mi oznámiti, kterakž se V. M. čeládka má, zase-li jsou zdrávi a umřel-li jest který z nich; mojit’ se zde všichni zase dobře mají.

(1558; SPP:101)

'I ask Your Grace to be so kind as to let me know how those in Your Grace's household are, are they healthy again or AUX any of them died [have... died]? Mine here are all well again.'

c. Psaní V. M., [...] jest mne došlo, kterémuž jsem porozuměla.

(1585; SPP: 137)

'Your Grace's letter, [...] AUX came [has come] to me, which I have understood.' 
The distinction between Old and Middle Czech auxiliated and unauxiliated pf $l$-participles in Letters $1365-1615$ is not identical to that between the Russian pf past expressing the presence of a result and the impf past expressing the cancellation of a result. For one thing, the effect of temporal adverbials in cases of the presence of a result, as in example (12a) in section 3.2 and (16a-b), in which there is no auxiliary, disrupts the equivalency. However, the lack of an auxiliary in the predicates with a current result in $(16 a-b)$, i.e., the bringing of the spoons and the handing over of the letter, is to be expected in sequential chains of events. Compare, for instance, the English He has brought the spoons versus He came and brought/*has brought the spoons. The Czech data reflect the same prohibition on mixing perfect with non-perfect forms that exists in English.

Even if the distinction coded by auxiliary variation in Old and Middle Czech is not identical to the distinctions coded by the Old Russian PF : IMPF opposition, what is important is that Old and Middle Czech continued to express a distinction or distinctions vaguely similar to that between the presence of a result and its cancellation with its past-tense morphology. This is in all likelihood an important contributing factor to the failure of the Czech aspectual system to develop the two-way impf as a major usage type, which is one of the defining features of the East Slavic aspectual system. There were certainly other factors at work that cannot be discussed here; these include the development of a resultative habeo factum construction in Czech, ${ }^{21}$ as well as several other indirectly related factors that did or may have involved

21 The Czech habeo factum construction, consisting of an inflected form of mit 'have' and a past passive participle (originally agreeing in gender, number, and case with an object) is attested as early as the mid-fifteenth century. An example is given in (i).

(i) A pro jejie velikú krásu měl ji ústavně zamčenú na nějakéj věži, aby ode všech nebyla ohlédána. (mid-15th cent.; SKZL)

'And because of her great beauty he had her continually locked up in some tower, so she would not be viewed by anyone.'

At some point this construction began to function as a perfect construction (consisting of an unagreeing neuter singular past passive participle) for many speakers, as exemplified in (ii).

(ii) Už máš objednáno?

'Have you already ordered?'

Determining the chronology of its development lies beyond the scope of this article. 
German and/or Latin language contact (for an example, see Dickey 2011).

\section{Concluding Remarks}

This paper has argued that there was a semantic motivation for auxiliary variation in the third-person forms of the Old and Middle Czech compound preterit. Namely, it expressed a distinction between current relevance/emphasis (auxiliated $l$-participles) and a neutral past-tense construal (unauxiliated $l$-participles). This distinction appears to have developed as the use of the aorist was curtailed in narrative contexts. Thus, unauxiliated $l$-participles effectively took over the narrative function of the aorist, whereas auxiliated $l$-participles remained to express the current relevance of the situation in the current discourse and/or an emphasis on the situation as important as such in the experience of the speaker. These two meanings are not necessarily exclusive; given that they were expressed by the same form, it is quite possible that they were not conceptually distinguished in the Czech verbal system. The inclusion of data from private correspondence from 1365 to 1615 reduces the likelihood that the effects seen in the two late fourteenth-century narratives, Asenath and The Life of Adam and Eve, are an artificial feature of a conservative literary style.

In this light, it is interesting to consider early sixteenth-century editorial criticisms, made by the grammarians Philomates and Jan Blahoslav, of the inclusion of third-person perfect auxiliaries in translations (these are cited by Gebauer 1958: 421). Given the data in Letters 1365-1615, I consider it possible that Philomates and Blahoslav were reacting to inappropriate, conservative perfect auxiliation in translations of narratives (as opposed to direct discourse where perfects are more appropriate). If not, there is a puzzling contradiction here, because auxiliation appears to have been alive and well in Czech private correspondence through the mid-sixteenth century.

The evidence that auxiliary variation with the $l$-participle reflected alternative construals of the situation profiled by the verb makes it difficult to simply attribute the loss of the auxiliary directly to the typologically common zero-marking of the third person. If markedness is at work here, it would be a conceptual unmarkedness of a third-person preterit with respect to current relevance vs. a neutral past-tense con- 
strual. Finally, a redundancy in agreement marking cannot explain the data presented here either.

The hypothesis developed here assumes that, before the Czech auxiliaries were grammaticalized as tense and person markers, the compound preterit paradigm was organized around default construals with respect to grounding. The retention of the auxiliary in the first and second person reflected a default of accessing the event profiled by these verb forms via the reference point of the speaker's experiential domain as an element of the ground, i.e., speech situation; the loss of auxiliaries in the third person reflected a default of no obligatory access via such a reference point. Thus, this account assumes a semantically heterogeneous paradigm structure for the preterit in Old and much of Middle Czech. This idea may sound counterintuitive, but it generally comports with the conclusions reached by Nesset and Janda (2010) regarding the uneven change of suffix shift to aj-stem forms in Russian verb paradigms, in which they demonstrate that Russian verbal paradigms are structured based on the prototypicality of the forms in terms of FINITE vs. NON-FINITE, and within FINITE according to person. Though the analysis presented here does not involve the prototypicality of verb forms directly, it fully supports Nesset and Janda's conclusion that paradigm structure is "motivated on semantic grounds" (722) and that it can affect language change.

The analysis here provides a principled way of motivating the lack of the development of the two-way impf in Czech, which adds to our understanding of the ways in which the aspect category came to function differently in the different Slavic languages. As mentioned in section 4, this is only one factor, and the development of the Czech habeo factum construction in particular must be relevant here. Others must have been involved as well, since Bulgarian, which retains both the aorist and compound perfect, has a higher degree of general-factual usage of the impf than Czech, though not to the degree of Russian. These factors presumably include the effects of certain kinds of prefixation models and language contact, among others, but these issues cannot be taken up here.

Lastly, as mentioned in section 1, this analysis is in the spirit of recent work by Fielder (e.g., 1998, 2001) in that it takes the semantic meaning of identity of byti 'be' seriously. If, as argued here, the Old and Middle Czech third-person perfect auxiliary signaled that the event in question was accessed through the experiential domain of the 
speaker, this allows us to link the Czech data to the renarrated (nonwitnessed) uses of unauxiliated l-participles in Bulgarian. This may be seen in example (iii) in footnote 17, in which the witnessed arrival of the information is coded with an auxiliary, whereas the reported actions of the horsemen are coded with unauxiliated l-participles. Such similarities open the possibility of a more comprehensive semantic analysis of the fate of third-person auxiliaries of the erstwhile compound perfect across Slavic, but this is a subject for future investigation. Accounting for the meaning of byti 'be' as an auxiliary in earlier stages of Slavic is the only reasonable approach in Cognitive Grammar, and it is also the only reasonable approach given a data set where auxiliary variation is demonstrably linked to specific variables (such as temporal location, etc.). Here we see the benefit of statistical methodologies such as random forest analysis.

\section{References}

Andersen, Henning. (1987) "From auxiliary to desinence". Martin Harris and Paolo Ramat, eds. Historical development of auxiliaries. Berlin: Mouton de Gruyter, 21-51.

—. (2006) "Grammation, regrammation, and degrammation". Diachronica 23(2): 231-58.

Dahl, Östen. (2004) The growth and maintenance of linguistic complexity. Amsterdam: John Benjamins.

Darden, Bill J. (2004) "A history of the East Slavic imperfect". Paper presented at the 2004 Conference of the American Association for the Advancement of Slavic Studies. Available at http://www.billdarden. com/papers/darden_2004_eslav_imperf.pdf.

Dickey, Stephen M. (2000) Parameters of Slavic aspect. Stanford, CA: CSLI Publications.

. (2011) "The varying role of po- in the grammaticalization of Slavic aspectual systems: Sequences of events, delimitatives, and German language contact". Journal of Slavic linguistics 19(2): 175230.

. (2012) "On the development of the Russian imperfective general factual". Scando-slavica 58(1): 7-48. 
Dostál, Antonín. (1966) “Několik poznámek k staročeským préteritům". Slavica pragensia 8: 79-85.

Długosz-Kurczabowa, Krystyna and Stanisław Dubisz. (2001) Gramatyka historyczna jezyka polskiego. Warsaw: Wydawnictwa Uniwersytetu warszawskiego.

Fielder, Grace. (1998) "Discourse function of past tenses in pre-modern Balkan Slavic prose". Alan Timberlake and Michael Flier, eds. Proceedings of the Twelfth International Congress of Slavists. Bloomington, IN: Slavica, 344-61.

. (2001) "Questioning the dominant paradigm: An alternative view of the grammaticalization of the Bulgarian evidential". Victor A. Friedman and Donald Dyer, eds. Of all the Slavs my favorites: In honor of Howard I. Aronson on the occasion of his 66th birthday. Bloomington, IN: Slavica Publishers, 171-201.

Friedman, Victor. (1986) "Evidentiality in the Balkans: Bulgarian, Macedonian, and Albanian". Johanna Nichols and Wallace Chafe, eds. Evidentiality: The linguistic coding of epistemology. Norwich, NJ: Academic Press, 168-89.

Gebauer, Jan. (1958) Historická mluvnice jazyka českého. Díl III. Tvarosloví. II. Časovaní. Prague: Náklad České akademie věd a umění.

Greenberg, Joseph H. (1966) Language universals: With special reference to feature hierarchies. The Hague: Mouton.

Haspelmath, Martin. (2006) "Against markedness (and what to replace it with)". Journal of linguistics 42(1): 25-70.

Lamprecht, Arnost, Dušan Šlosar, and Jaroslav Bauer. (1986) Historická mluvnice češtiny. Prague: Státní pedagogické nakladatelství.

Langacker, Ronald. (1990) Concept, image, and symbol. Berlin: Mouton de Gruyter.

(1999) "Losing control: Grammaticization, subjectification, and transparency". Andreas Blank and Peter Koch, eds. Historical semantics and cognition. Berlin: Mouton de Gruyter, 147-75.

Ming, Tao. (2010) "Review of Richiard Xiao and Tony McEnery (2004) Aspect in Mandarin Chinese: A corpus based study". Chinese language and discourse 1(1): 138-44.

Nesset, Tore and Laura A. Janda. (2010) "Paradigm structure: Evidence from Russian suffix shift". Cognitive linguistics 21(4): 699-725. 
Reindl, Donald. (2005) The effects of historical German-Slovene language contact on the Slovene language. Ph.D. dissertation, Indiana University.

Strobl, Carolin, James Malley, and Gerhard Tutz. (2009) “An introduction to recursive partitioning: Rationale, application, and characteristics of classification and regression trees, bagging, and random forests". Psychological methods 14(4): 323-48.

Tommola, Hannu. (2000) "On the perfect in North Slavic". Östen Dahl, ed. Tense and aspect in the languages of Europe. Berlin: Mouton de Gruyter, 441-78. [Empirical approaches to language typology, 20-6.]

Xaburgaev, Grigorij. A. (1978) “Sud'ba vspomogatel'nogo glagola drevnix slavjanskix analitičeskix form v russkom jazyke". Vestnik Moskovskogo universiteta: Serija filologičeskaja 4: 42-53.

Zaliznjak, Andrej A. (2004) Drevnenovgorodskij dialekt. Moscow: Jazyki slavjanskoj kul'tury.

. (2008) Drevenerusskie ènklitiki. Moscow: Jazyki slavjanskoj kul'tury.

\section{Sources}

AČČSPP = František Palacký, ed. (1872) Archiv český čili staré písemné památky české i morawské. Díl šestý. Prague: Knihkupec Fridrich Tempský.

AI1 = Arxeografičeskaja komissija. (1841) Akty istoričeskie. Tom pervyj 1334-1598. St. Petersburg: Tipografija II-go otdelenija sobstvennoj E. I. V. kanceljarii.

Alex $=$ Alexander. Jaroslav Kolár and Milada Nedědová, eds. (1983) Próza českého středověku. Prague: Odeon, 21-147.

Asen $=$ Asenech . Jaroslav Kolár and Milada Nedědová, eds. (1983) Próza českého středověku. Prague: Odeon, 339-48.

CČJE = Kabátník, Martin. Cesta z Čech do Jeruzaléma a Egypta r. 14911492. Available at http://vokabular.ujc.cas.cz/moduly/edicni/edice/ f2fe276a-a434-47ed-bf06-4b7a7637bf9a/plny-text/s-aparatem/folio/182v.

$L A E=\check{Z}$ ivot Adama a Evy. Jaroslav Kolár and Milada Nedědová, eds. (1983) Próza českého středověku. Prague: Odeon, 295-307.

PGII = A. L. Choroškevič, ed. (1978) Polockie gramoty XIII-načala XVI vv. 2. Moscow: Institut istorii AN SSSR. 
SKZL = Sbirka kázání založených na legendách. Available at http:// vokabular.ujc.cas.cz/moduly/edicni/edice/fa10177b-25e6-4bb6-b061Odb988ad3840/plny-text/s-aparatem/folio/1v.

SPP = František Dvorský, ed. (1869) Staré písemné památky žen a dcer českých. Prague: Náklad vlastní-v komisí kněhkupectví F. Řívnáče.

University of Kansas

Dept. of Slavic Languages and Literatures

2133 Wescoe Hall

Lawrence, KS 66045

USA

smd@ku.edu
Received: August 2012

Revised: January 2013 